\title{
Geochemistry of Early Devonian calc-alkaline plutons in the Merrimack Belt: implications for mid-Paleozoic terrane relationships in the New England Appalachians
}

\author{
Brandon G. Watts ${ }^{1 *}$, Michael J. Dorais ${ }^{2 \S}$, and Robert P. Wintsch ${ }^{3}$ \\ ${ }^{I}$ Department of Geological Sciences, Indiana University, Bloomington, IN 47405, U.S.A. \\ ${ }^{2}$ Department of Geology, Brigham Young University, Provo, UT 84602, U.S.A. \\ $<$ dorais@byu.edu $>$ \\ ${ }^{3}$ Department of Geological Sciences, Indiana University, Bloomington, IN 47405, U.S.A. \\ $<$ wintsch@indiana.edu> \\ *Current address: Earth Tech Inc. 1420 King Street, Suite 600, Alexandria, VA 22314, \\ U.S.A. <Brandon_Watts@earthtech.com> \\ ${ }^{\S}$ Corresponding author
}

Date Received: February 4, 2000

Date Accepted: February 3, 2001

\begin{abstract}
A series of northeast-trending plutons extending from northeastern Massachusetts to southeastern Maine intruded the metasedimentary rocks of the Merrimack belt. The Early Devonian Dracut, Sweepstakes, Island Pond, Exeter, and Webhannet plutons are metaluminous and, with the exception of the granitic Webhannet pluton, are dominantly mafic to intermediate in composition. The plutons are calc-alkaline in character and have major, minor, and trace element compositions typical of magmas generated at destructive plate margins. These characteristics include mid- to high-K contents, enrichment of LILE, LREE, $\mathrm{Ba}$, and $\mathrm{Sr}$, and negative $\mathrm{Nb}$ and $\mathrm{Ta}$ anomalies.

Whole-rock chemical data indicate that the plutons of the Merrimack belt are similar in every measured geochemical parameter to ca. $400 \mathrm{Ma}$ mafic to intermediate rocks of the New Hampshire Plutonic Suite. These similarities suggest that both groups of plutons were emplaced within the same magmatic arc and belong to the same magmatic suite. A magmatic suite common to both the Merrimack belt and Central Maine terrane suggests that the two lithotectonic zones were proximal to each other at ca. $400 \mathrm{Ma}$. Trace element differences between Merrimack belt and Sharpners Pond rocks suggest that the Putnam-Nashoba terrane represents a separate arc.

Located in the Central Maine terrane of New Hampshire, the Rochester pluton is geochemically distinct from the Siluro-Devonian plutons of the Merrimack belt and New Hampshire Plutonic Suite. The Rochester pluton has alkaline affinities but retains overall calc-alkaline features. High concentrations of incompatible elements $(\mathrm{K}, \mathrm{Ti}, \mathrm{P}, \mathrm{Ba}, \mathrm{Rb}, \mathrm{Zr})$ in the Rochester pluton are markedly similar to those observed in the $360 \mathrm{Ma}$ Hardwick Tonalite of Massachusetts. The strong geochemical correlation between the Rochester and Hardwick plutons implies derivation from the same magmatic event and a common, Late Devonian origin. We suggest that these plutons may have originated in response to pull-apart rifting related to late-stage Acadian transpression.
\end{abstract}

Une série de plutons orientée vers le nord-est s'étendant du nord-est du Massachusetts au sud-est du Maine, fait intrusion dans les roches métasédimentaires de la ceinture de Merrimack. Les plutons du Dévonien inférieur Dracut, Sweepstakes, Island Pond, Exeter et Webhannet constituent des intrusions métalumineuses et, mis à part le pluton granitique Webhannet, ils ont une composition en prédominance mafique à intermédiaire. Les plutons ont une conformation calcoalcaline et leur composition du point de vue des principaux éléments présents, de ceux présents en quantité restreinte et des éléments traces est représentative des magmas produits aux frontières de plaques destructives. Leurs caractéristiques comportent notamment une teneur moyenne à élevée en potassium, un enrichissement en LILE, en éléments de terres rares légères, en BA et en $\mathrm{SR}$, de même que des anomalies négatives de $\mathrm{Nb}$ et $\mathrm{Ta}$.

Les données de la roche totale révèlent que les plutons de la ceinture de Merrimack sont semblables, sous le rapport de chacun des paramètres géochimiques mesurés, aux magmas mafiques à intermédiaires d'il y a environ 400 Ma du cortège plutonique du New Hampshire. Ces similarités permettent de supposer que les deux groupes de plutons ont été insérés à l'intérieur du même arc magmatique et qu'ils appartiennent au même cortège magmatique. L'existence d'un cortège magmatique commun à la ceinture de Merrimack et au terrane de Central Maine permet de supposer que les deux zones lithotectoniques étaient proximales l'une de l'autre il y a environ $400 \mathrm{Ma}$. Les différences par rapport aux éléments traces entre les magmas de la ceinture de Merrimack et ceux de Sharpners Pond laissent supposer que le terrane de Putnam-Nashoba représente un arc distinct.

Le pluton Rochester, situé dans le terrane de Central Maine du New Hampshire, est géochimiquement distinct des plutons siluro-dévoniens de la ceinture de Merrimack et du cortège plutonique du New Hampshire. Le pluton Rochester présente des affinités alcalines tout en conservant ses caractéristiques calco-alcalines générales. Les concentrations élevées 
d'éléments incompatibles $(\mathrm{K}, \mathrm{Ti}, \mathrm{P}, \mathrm{Ba}, \mathrm{Rb}, \mathrm{Zr})$ dans le pluton Rochester sont manifestement semblables à celles observées dans la tonalite d'il y a $360 \mathrm{Ma}$ de Hardwick, au Massachusetts. La corrélation géochimique prononcée entre les plutons Rochester et Hardwick suppose qu'ils découlent du même phénomène magmatique et qu'ils ont une origine commune remontant au Dévonien supérieur. Nous pensons que ces plutons tirent probablement leur origine d'une réaction à une distension d'écartement apparentée à une transpression acadienne tardive.

Traduit par la rédaction

\section{INTRODUCTION}

Geochronological and geochemical studies in the last two decades have led to the recognition of several distinct lithotectonic zones along the eastern margin of the Appalachian Orogen in New England (Lyons et al. 1982; Zen 1983; Zartman 1988; Rankin 1994; Robinson et al. 1998). With this understanding has come controversy regarding the timing of their assembly and thus their relative contributions to the building of the orogen (Wintsch and Sutter 1986; Hatcher 1989; Armstrong et al. 1992; Thompson et al. 1992; Wintsch et al. 1992; Eusden and Lyons 1993; Rast and Skehan 1993; Wintsch et al. 1993). Unravelling the tectonic history of these lithotectonic terranes is complicated by the presence of multiple Paleozoic metamorphic and deformational events
(Armstrong et al. 1992), the absence of fossil control, and generally poor exposure.

The Early to Middle Devonian Acadian orogeny is a tectonic event that has traditionally been attributed to the accretion of Avalonia to the North American craton (Osberg 1978; Dallmeyer et al. 1981; Williams and Hatcher 1983). Caught between the Putnam-Nashoba and Avalon composite terranes to the east and the Central Maine Terrane to the west (Fig. 1), the Merrimack belt is an enigmatic block in the orogen. Understanding its tectonic history is essential to understanding the assembly of the eastern terranes to central New England.

The presence of Late Silurian-Early Devonian calcalkaline intrusive rocks in both the Putnam-Nashoba and

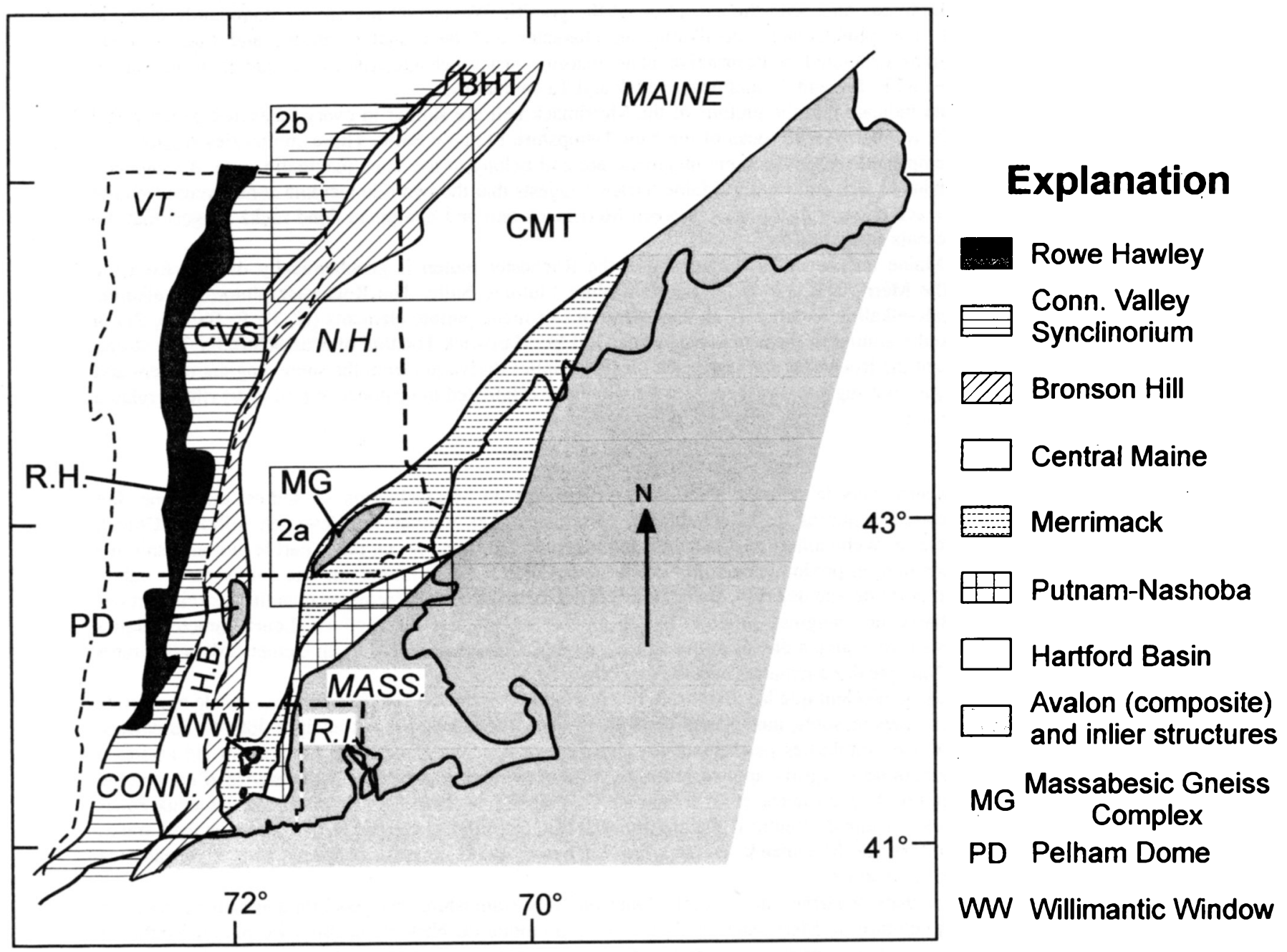

Fig. 1. Generalized geologic map of New England (after Wintsch et al. 1992) showing the distribution of lithotectonic zones in the Appalachian orogen. Area 2a - study area shown in detail in Fig. 2a. Area 2b - location of New Hampshire Plutonic Suite intrusions shown in Fig. 2b. 
Central Maine terranes (Fig. 2) suggests that these zones were proximal to convergent plate margins during this time. Numerous hypotheses have been presented regarding the nature of these inferred subduction zones and their relationship to the tectonic assembly of the region. Several researchers (McKerrow and Ziegler 1971; Bradley 1983; Ludman et al. 1993) have suggested the presence of two Acadian subduction zones of opposite polarity on both margins of a closing intraplate basin to explain the distribution of arc-related extrusive and intrusive rocks in New England (Fig. 3a). Three potential models can explain the subsequent amalgamation and tectonic relationship of the Central Maine terrane, Merrimack belt, and Putnam-Nashoba terrane during the Late Silurian-Early Devonian. The first possibility is that the Merrimack belt sedimentary rocks constitute a distinct terrane that was accreted to the North American continent, with subduction of the lapetus Ocean generating magmas of the New Hampshire Plutonic Suite and the Merrimack belt after accretion. "These magmas would have been contemporaneous, belonging to the same magmatic arc (Fig. $3 b$ ). A subvarient of this model is that the Merrimack belt was originally part of North America and was transposed to its present position by strike-slip faults after emplacement of the New Hampshire Plutonic Suite and Merrimack belt plutons.

A second possibility is that the Merrimack belt was formed outboard of North America and that the magmas of the Merrimack belt were generated by an eastward-dipping subduction zone beneath a previously assembled Merrimack belt, Putnam-Nashoba terrane, and Avalon terrane (Fig. 3c; Hepburn et al. 1995). In this scenario, the Merrimack belt plutons would be related to additional plutons farther east in the Putnam-Nashoba zone (Sharpners. Pond) and Avalon terrane (Cape Ann). The third possibility is that the Merrimack belt and its associated plutons were formed independently of both North America and Putnam-Nashoba and are indeed a distinct terrane (Fig. 3d). The Early Devonian plutons of the intervening Merrimack belt, their tectonic affinity and relation to temporally equivalent intrusions in surrounding terranes, have been the subject of relatively little research.

In order to constrain which of these scenarios is most appropriate for the origin of the Merrimack belt and its plutons, five plutons in the Merrimack belt and one from the Central Maine terrane were selected for geochemical study. In this paper we summarize the whole-rock and mineral chemistry of these plutons. On the basis of these data we test the proposed models in Fig. 3 and address the following questions: (1) What was the tectonic setting in which the Devonian plutons of the Merrimack belt were generated and emplaced? (2) How do these magmas compare to SiluroDevonian plutons produced at convergent plate margins in adjacent terranes? Did they originate in a common arc with either of the two neighbouring magmatic suites, or do they represent a geochemically distinct and thus tectonically unique event? If the Merrimack belt and either the Putnam-Nashoba or Central Maine terranes were juxtaposed prior to subduction-related magmatism, a close geochemical and temporal relationship between the plutons of the two lithotectonic zones would be expected.

\section{GEOLOGICAL SETTING}

\section{Central Maine terrane}

In central New Hampshire, metasedimentary rocks of the Central Maine terrane are predominantly metapelitic rocks comprising the Silurian Rangeley, Perry Mountain, Smalls Falls, and Madrid formations. These units are overlain by the Lower Devonian Littleton Formation and all are metamorphosed to amphibolite facies. The majority of the Silurian sediments were derived from source rocks to the west of a deep-water depositional basin that closed in the middle Devonian (Hatch et al. 1983; Moench and Pankiwskyi 1988, Osberg 1978; Dallmeyer et al. 1981; Williams and Hatcher 1983). The Littleton Formation consists of turbidites and minor amounts of volcanic rocks derived from an eastern source (Roy and Mencher 1976). All these formations experienced multiple episodes of deformation, which are presumed to be Acadian (Englund 1976; Nielson 1981; Lyons et al. 1982; Thompson et al. 1992; Eusden and Lyons 1993). Metamorphic grade is universally upper amphibolite facies, probably peaking in the early Devonian (Eusden and Barriero 1988).

Extensive granitoid magmas of the syn- to post-tectonic Devonian New Hampshire Plutonic Suite intruded the metasedimentary rocks of the Central Maine terrane. In New Hampshire, most of these plutons are felsic with only the Spaulding tonalite member of the New Hampshire Plutonic Suite containing relatively significant amounts of mafic to intermediate rocks. Mafic to intermediate plutons of the same age are more abundant in northeastern Vermont and western Maine (Moench and Pankiwskyi 1988; Nielson et al. 1989; Ayuso and Arth 1992; Dorais and Paige 2000), having intruded the Connecticut Valley belt, the Bronson Hill Anticlinorium, and the Central Maine terrane.

\section{Merrimack belt}

The Merrimack belt is a NNE-trending belt of metasedimentary rocks stretching from southern Connecticut to the Casco Bay area in southeastern Maine (Hussey and Bothner 1993). This sequence of Silurian(?) or older rocks (Aleinikoff et al. 1995) is composed of calcareous metasiltstone and argillaceous metasedimentary rocks of the Eliot, Berwick, and Kittery formations of the Merrimack Group in New Hampshire, the Oakdale Formation in Massuchusetts, and the Hebron gneiss in Connecticut. The intensity of metamorphism varies along and across strike. The metamorphic grade of the Merrimack belt increases to the west from garnet- to sillimanite-grade in Connecticut (Wintsch et al. 1993), from chlorite to andalusite in Massachusetts (Robinson 1981), and from chlorite to kyanite \pm sillimanite in New Hampshire (Lyons et al. 1997; Kunk and Wintsch, unpublished data). In both Connecticut and New Hampshire, ${ }^{40} \mathrm{Ar} /{ }^{39} \mathrm{Ar}$ thermochronologic data (Wintsch et al. 1992) show that the higher grade, western portion of the belt was remetamorphosed in the Alleghenian, making the discrimination of overprinting fabrics difficult to interpret. A series of intrusions ranging in composition from gabbro to granite and generally becoming more felsic to the north 


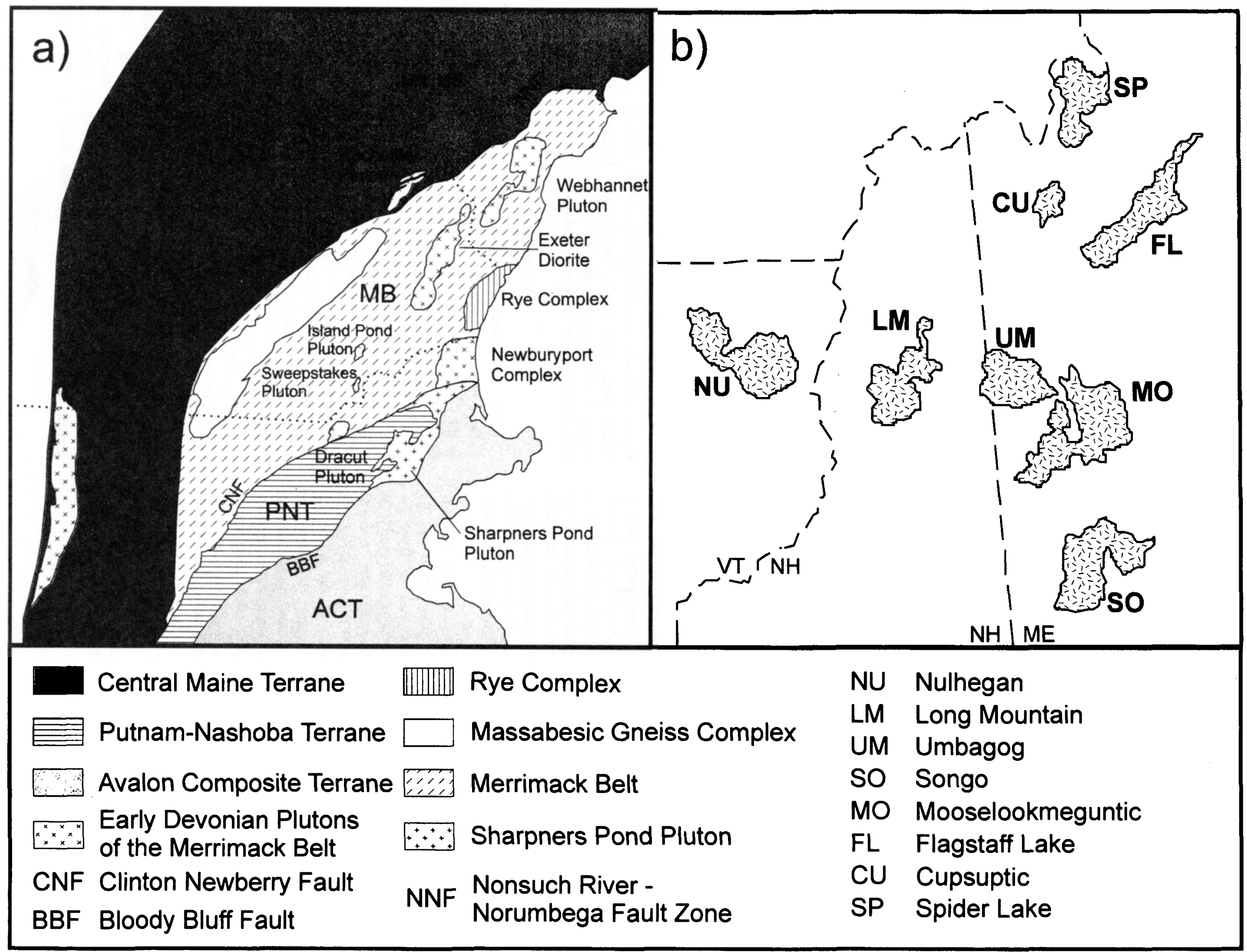




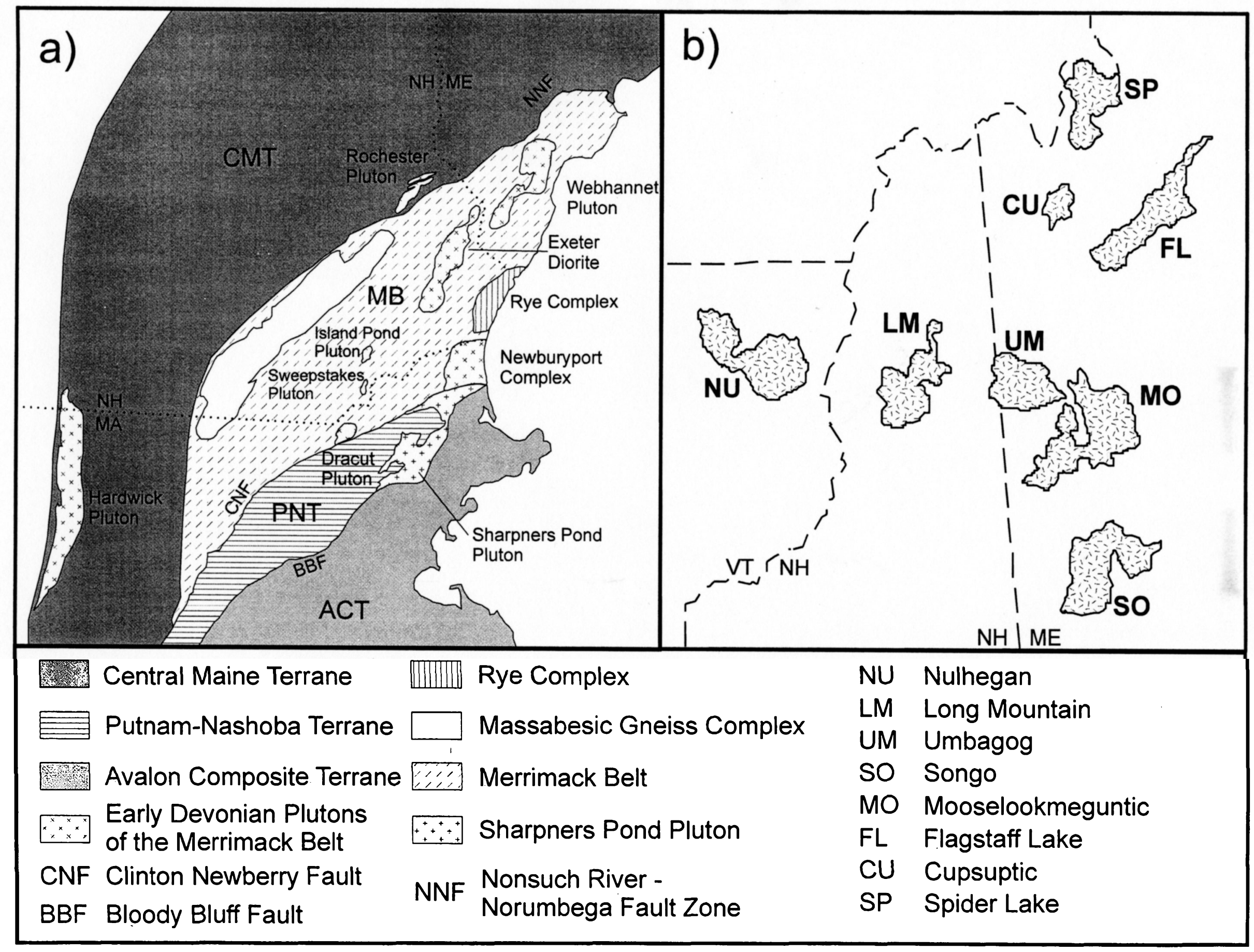



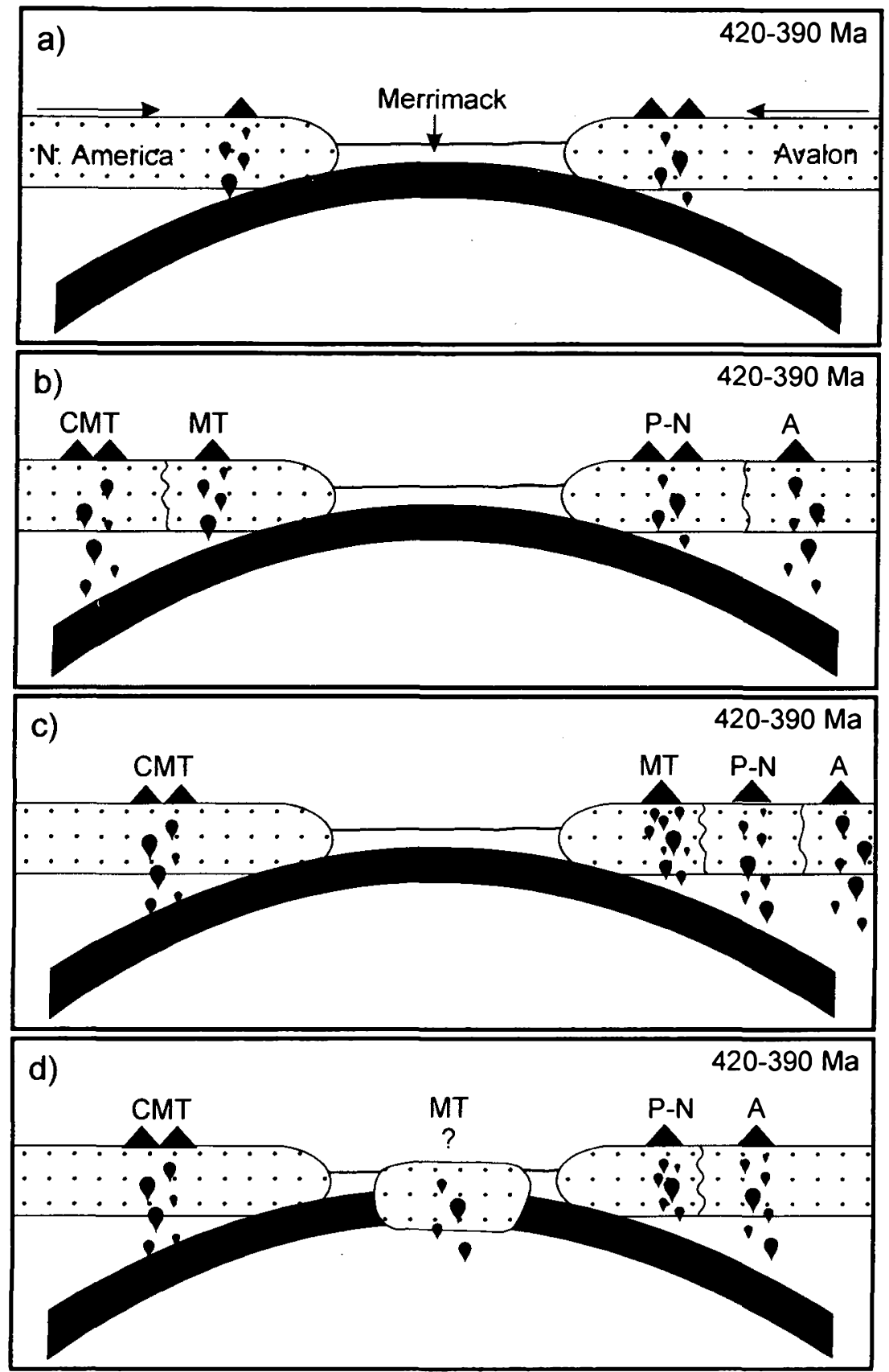

Fig. 3. Schematic diagram showing potential models for Late Sillurian - Early Devonian magmatism in the Central Maine terrane, Merrimack belt, Putnum-Nashoba terrane, and the Avalon terrane. a) Mollocca Sea type collision as visualized by various workers; $b-d)$ Potential tectonic models (see text for discussion). $\mathrm{CMT}=$ Central Maine terrane; $\mathrm{MT}=$ Merrimack belt; $\mathrm{P}-\mathrm{N}=$ Putnum-Nashoba terrane; $\mathrm{A}=\mathrm{Avalon}$ Composite terrane.

intruded the tightly folded metasedimentary rocks Merrimack Group.

\section{Putnam-Nashoba terrane}

The Putnam-Nashoba terrane is composed of mafic metavolcanic and pelitic metasedimentary rocks (Goldsmith 1991) that are Late Cambrian to Early Ordovician in age
(Hepburn et al. 1995). Post-metamorphic Late Silurian plutons of intermediate to granitic composition, including the $430 \pm 5$ Ma Sharpners Pond Diorite (Zartman and Naylor 1984), intruded the metasedimentary rocks of the Putnam-Nashoba terrane (Loftenius 1988).

Fig. 2 a). Simplified geologic map showing the distribution of Early Devonian plutonic rocks of the Merrimack belt and selected plutons and tectonic features of adjacent lithotectonic zones. b). Map showing locations of New Hampshire Plutonic Suite plutons selected for geochemical comparison. 


\section{Ductile faults and lithotectonic boundaries}

Ductile faults on the eastern and western margin of the Merrimack belt separate it from packages of metasedimentary rocks with distinct thermal and metamorphic histories. The Norumbega fault system delineates the western boundary of the Merrimack belt and separates it from the Central Maine terrane. The eastern boundary between the Merrimack belt and the Putnam-Nashoba terrane is marked by the ClintonNewbury fault and its extensions.

\section{Tectonic/lithostratigraphic relationships among lithotectonic zones}

Despite the thermal and metamorphic discontinuities observed across the Norumbega fault system (West et al. 1993), there is considerable debate regarding correlation of metasedimentary sequences of the Merrimack belt and Central Maine terrane and their potential stratigraphic and temporal relationship (Lyons et al. 1982; Bothner et al. 1984; Robinson et al. 1998; Bothner and Hussey 1999). The age of the Exeter pluton initially obtained by Gaudette et al. (1984) as $473 \pm 37$ Ma constrained the minimum age of the host metasedimentary rocks as Early Ordovician to Late Proterozoic. This age implied that the metasedimentary rocks of the Merrimack belt were older than the Silurian Central Maine terrane to the west and "exotic" to North America (Bothner et al. 1984; Olszewski and Gaudette 1988). Subsequent, more precise U$\mathrm{Pb}$ dating of the Exeter pluton $(406 \pm 3 \mathrm{Ma}$, Bothner et al. 1993) has demonstrated that the minimum depositional age of the Merrimack belt metasedimentary rocks is Late Silurian and precludes the designation of the Merrimack belt as a separate terrane on the basis of age alone.

Some workers have suggested that the Berwick Formation of the Merrimack belt is very similar to what was called the Vassalboro formation (now the Hutchins Corner Formation, Bothner and Hussey 1999) of the Central Maine terrane in Maine and the Paxton and Oakdale formations of Massachusetts (Billings 1956; Hussey 1962; Osberg 1980; Hussey et al. 1986). If these formations are indeed the same, then the suggestion that the Merrimack belt is a separate lithotectonic zone from the Central Maine terrane is negated (Robinson et al. 1998). Additionally, the Merrimack belt metasedimentary rocks contain detritial zircon as young as $420 \mathrm{Ma}$ (Aleinikoff et al. 1995), indicating a Silurian or Early Devonian age of deposition, and thereby allowing correlation of the Central Maine terrane and Merrimack belt sequences (Bothner and Hussey 1999). In contrast, the Late Proterozoic to Early Paleozoic metasedimentary rocks of the PutnamNashoba terrane have a geologic history distinct from those of the Merrimack belt (Hepburn et al. 1995).

Within the Merrimack belt, a series of Early Devonian, mafic to intermediate intrusions extends from north-central Massachusetts to southeast Maine (Fig. 2). Previous studies (Billings 1956) grouped the mafic plutons of southeast New Hampshire as a distinct magmatic suite called the Hillsborough Plutonic Series. Based on similar ages, the Hillsborough Plutonic Series has subsequently been correlated with the New Hampshire Plutonic Suite (Lyons et al. 1997) of the Central Maine terrane (a U-Pb age of $406 \pm 3 \mathrm{Ma}$ for the Exeter Pluton; Bothner et al. 1993). Although the mafic and intermediate plutons of adjacent lithotectonic terranes have been the focus of several regional geochemical surveys (Zartman and Naylor 1984; Ayuso and Arth 1992; Hon et al. 1993; Hepburn et al. 1995; Dorais and Paige 2000), limited geochemical data exist for the plutons of the Merrimack belt. Acquisition of petrochemical data for these rocks enables a more detailed interpretation of the tectonic setting in which they were emplaced which is important in reconstructing the geologic history of the region.

\section{SAMPling Strategy and ANAlytical METHODS}

The plutons of the Merrimack belt generally become more felsic from south to north. Each of the plutons shows varying degrees of compositional zoning and/or bimodal composition. Rocks representing the range of compositions for each pluton were selected in order to characterize this suite of rocks. Special emphasis was placed on mafic samples for several reasons. First, it is expected that the mafic rocks within the Merrimack belt have experienced relatively little crustal contamination and reflect most closely the geochemical characteristics of the original magmas and source regions. Additionally, comparison of the most primitive samples available yield the most information about the possible genetic relations of the magmas among the various lithotectonic zones and facilitate evaluation of the competing tectonic models presented in Fig. 3.

With this in mind, we selected samples displaying textures and whole-rock chemistry most representative of primitive liquids to compare with temporally and compositionally equivalent rocks in adjacent lithotectonic zones. Primitive, relatively uncontaminated mafic rocks are scarce within the New Hampshire Plutonic Suite. The best candidates for comparison are a series of mafic plutons located in northern Vermont, New Hampshire, and western Maine (Fig. 2b) spanning the Connecticut Valley, Bronson Hill, and Central Maine terranes. With the exception of the peraluminous Long Mountain pluton of northern New Hampshire, these plutons are metaluminous and have low $\delta^{18} \mathrm{O}$ values (Dorais and Paige 2000.) indicative of relatively primitive melts. Likewise, the gabbro and diorite of the Sharpners Pond pluton represent similar intrusive rocks in the Putnam-Nashoba terrane. The $360 \pm 1$ Ma Hardwick pluton (Tucker and Robinson 1995), which represents a younger magmatic event within the Central Maine terrane, is used for geochemical comparison.

Major, minor, and selected trace element analyses were conducted using XRF techniques at the Nova Scotia Regional Geochemical Centre, St. Mary's University, Nova Scotia. Additional trace and rare earth element data were obtained by INAA performed at the Phoenix Memorial Laboratory at the University of Michigan. Mineral composition data were collected at Indiana University using a Cameca SX50 electron microprobe with $15 \mathrm{kV}$ accelerating voltage and $20 \mathrm{nA}$ beam current (10 nA, $10 \mu \mathrm{m}$ beam diameter for feldspar analyses). 


\section{Petrology and Petrography}

The sampled plutons of the Merrimack belt are composed dominantly of hornblende-biotite diorites and granodiorites. Mineral assemblages and textures are igneous, but display variable amounts of sub-solidus alteration. A more detailed characterization of the six individual plutons is included below.

\section{Dracut Pluton}

The Dracut Pluton is exposed over an area of $70 \mathrm{~km}^{2}$ in north-central Massachusetts (Zen et al. 1983) in the southern portion of the Merrimack belt and intrudes the metasedimentary rocks of the Berwick Formation. Previous mapping and lithologic descriptions are given in Dennen (1943) and Hon et al., (1986). Rock compositions range from gabbro to tonalite, with fine- to medium-grained gabbro and diorite dominant. The pluton is heterogeneous on the outcrop scale, exhibiting considerable variability in grain size, phenocryst assemblage, and colour. The rocks are nonfoliated, and are crosscut by volumetrically minor pegmatitic veins. Despite the presence of magmatic sulphide and local alteration minerals, many of the mafic rocks retain igneous textures and assemblages with minimal deuteric overprint.

Primary igneous minerals include euhedral laths of plagioclase, biotite, pyroxene, and amphibole. Orthopyroxene is more abundant than clinopyroxene and occurs as subhedral phenocrysts, some largely replaced by amphibole. Clinopyroxene (diopside) occurs as scarce, ragged cores within amphibole and rarely coexists with orthopyroxene. Dark brown subhedral phenocrysts of Ti-rich amphibole are ophitic to subophitic and commonly have biotite replacement rims.

\section{Sweepstakes Pluton}

The Sweepstakes Pluton, located in southeastern New Hampshire, intrudes the Eliot Formation of the Merrimack Group (Sundeen 1971) and is the smallest body sampled ( 3.5 $\mathrm{km}^{2}$ ). The most abundant rock type is massive to moderately flow-banded diorite and quartz diorite. Several small bodies of coarse-grained norite cumulates occur in the centre of the body. With the exception of the northern portions of the Exeter pluton, the Sweepstakes shows the largest degree of sub-solidus alteration.

Minerals present include biotite, plagioclase, and light brown, secondary amphibole. Ilmenite is abundant and commonly rimmed by titanite overgrowths. Anhedral quartz is a minor, interstitial phase. Sericite commonly replaces plagioclase along cleavage planes. Other alteration products include epidote and minor chlorite.

\section{Island Pond Pluton}

Exposed approximately 6 kilometres to the north of the Sweepstakes Pluton, the Island Pond Pluton $\left(\sim 8 \mathrm{~km}^{2}\right)$ crops out as a northeast-trending elliptical body (Sundeen 1971). Contact relationships are difficult to discern due to exceedingly poor exposure. The pluton exhibits a bimodal range of rock compositions with two volumetrically subordinate bodies of coarse-grained, massive diorite in the core of the intrusion surrounded by massive to weakly foliated granitic rocks.

The diorite contains normally zoned suhedral to anhedral plagioclase phenocrysts typically ranging from $\mathrm{An}_{30}$ to $\mathrm{An}_{25}$. Pale to dark green amphibole is the dominant mafic silicate. $\mathrm{Fe}-\mathrm{Ti}$ oxides are common along cleavage planes in hornblende. Lesser amounts of pale green to light yellow biotite are also present.

\section{Exeter Pluton}

The largest body $\left(\sim 130 \mathrm{~km}^{2}\right)$ sampled is the northeasttrending Exeter Pluton, located in southeastern New Hampshire. Dominantly dioritic in composition, the pluton is zoned from gabbro in the southwest to granodiorite at its northern end. The rocks are medium- to coarse-grained and massive in texture. Mafic rocks in the southern portion of the pluton generally retain much of their original igneous character whereas deuteric alteration is most pervasive in the northern portion of the pluton.

The mafic rocks consist of hornblende, orthopyroxene \pm clinopyroxene, biotite, plagioclase, and minor quartz. In some portions of the pluton, light to dark brown amphibole phenocrysts partially enclose normally zoned plagioclase laths in a subophitic texture. Other regions contain rocks with pale green phenocrysts of hornblende that are commonly intergrown with biotite. Ortho- and clinopyroxene occur as anhedral remnants partially replaced by amphibole. Alteration phases include actinolite and chlorite which are more abundant in the northern, more felsic portion of the pluton. Zircon and Fe-Ti oxides are common accessory minerals.

\section{Webhannet Pluton}

The northernmost and overall most felsic intrusion sampled from the Merrimack belt is the Webhannet Pluton which crops out over an are of $\sim 150 \mathrm{~km}^{2} 3$ kilometres east of the New Hampshire-Maine border in southeastern Maine (Osberg et al. 1985). The coarse-grained pluton is concentrically zoned from granodiorite at its margin to Kfeldspar megacrystic granite in the centre. Gaudette et al., (1982) reported a U-Pb zircon age of $403 \pm 14 \mathrm{Ma}$ for the Webhannet pluton.

Predominant minerals are potassium feldspar, quartz, and plagioclase. Perthitic microcline forms large (up to $12 \mathrm{~mm}$ ) phenocrysts. Biotite ranges from subhedral to interstitial. Subhedral to euhedral epidote crystals commonly have allanite cores and appear to be a primary magmatic phase. Apatite, zircon, and Fe-Ti oxides are common accessory minerals.

\section{Rochester Pluton}

The Rochester Pluton, located 15 kilometres northwest of the Exeter Pluton across the Norumbega fault system, is the only pluton of this study located in the Central Maine terrane. Rocks are medium- to coarse-grained diorite and exhibit moderate sub-solidus modification. With the exception of a poorly exposed fine-grained phase, the Rochester Pluton is similar in hand specimen to the Exeter Pluton.

Principle minerals are plagioclase and biotite. Plagioclase phenocrysts are subhedral to euhedral and show oscillatory zoning. Sericite partially replaces plagioclase in altered 
Table 1. Representative feldspar analyses, Merrimack Trough and Rochester plutons

\begin{tabular}{|c|c|c|c|c|c|c|c|c|c|c|c|c|c|c|}
\hline \multirow[b]{2}{*}{ Sample } & \multicolumn{14}{|c|}{ Plagioclase } \\
\hline & D-1-2a & $D-1-4 a$ & $D-4-1 a$ & $D-4-2 a$ & E-3-4ar & E-3-4ac & $E-4-1 a$ & $E-7-4 a$ & IP-5-Ia & IP-5-2a & IP-5-3a & IP-5-4a & $S-5-2 a$ & S-5-3ac \\
\hline $\mathrm{SiO}_{2}$ & 55.77 & 57.34 & 53.59 & 50.70 & 53.93 & 50.62 & 54.54 & 55.87 & 60.20 & 59.93 & 60.61 & 61.80 & 56.87 & 56.00 \\
\hline $\mathrm{Al}_{2} \mathrm{O}_{3}$ & 28.75 & 26.73 & 30.7 & 31.79 & 29.93 & 32.2 & 28.9 & 27.7 & 25.12 & 25.24 & 25.02 & 23.45 & 27.12 & 27.57 \\
\hline $\mathrm{CaO}$ & 10.82 & 9.07 & 12.14 & 14.73 & 11.90 & 15.2 & 10.88 & 10.13 & 6.00 & 6.43 & 5.85 & 4.22 & 0.15 & 0.03 \\
\hline $\mathrm{Na}_{2} \mathrm{O}$ & 5.29 & 6.36 & 4.57 & 3.30 & 4.75 & 3.05 & 5.2 & 5.62 & 8.08 & 7.76 & 8.14 & 8.93 & 6.72 & 6.28 \\
\hline $\mathrm{K}_{2} \mathrm{O}$ & 0.31 & 0.14 & 0.03 & 0.00 & 0.05 & 0.04 & 0.23 & 0.15 & 0.11 & 0.22 & 0.11 & 0.08 & 0.06 & 0.16 \\
\hline \multirow[t]{2}{*}{$\% A n$} & 52 & 43 & 60 & 71 & 58 & 73 & 53 & 50 & 29 & 31 & 28 & 21 & 41 & 45 \\
\hline & \multicolumn{7}{|c|}{ Plagioclase } & \multicolumn{7}{|c|}{ K-feldspar } \\
\hline Sample & S-5-3ar & S-5-5a & $W-1-8 a$ & $W-1-8 \mathbf{a}$ & $W-1-11 a$ & W-1-10a & $\mathrm{R}-4-1 \mathrm{a}$ & $R-4-5 a$ & $R-5-4 a$ & $R-5-4 a$ & W-1-1a & $W-1-2 a$ & $W-1-3 a$ & $W-1-5 a$ \\
\hline $\mathrm{SiO}_{2}$ & 57.39 & 56.75 & 63.35 & 66.44 & 61.82 & 63.19 & 59.88 & 56.02 & 55.90 & 58.19 & 63.78 & 64.45 & 64.23 & 64.11 \\
\hline $\mathrm{Al}_{2} \mathrm{O}_{3}$ & 27.16 & 27.56 & 23.39 & 20.56 & 24.15 & 23.20 & 24.60 & 27.60 & 27.60 & 26.21 & 19.01 & 18.72 & 18.77 & 18.94 \\
\hline Total & 99.81 & 99.46 & 99.99 & 98.96 & 99.5 & 99.57 & $\overline{98.91}$ & 99.37 & 99.07 & 99.09 & 98.98 & 99.46 & 99.43 & 99.15 \\
\hline$\%$ An & 38 & 43 & 17 & 4 & 22 & 18 & 31 & 46 & 47 & 37 & & & & \\
\hline$\%$ Or & & & & & & & & & & & 93 & 92 & 94 & 90 \\
\hline
\end{tabular}

samples. Biotite is subhedral and contains abundant Fe-Ti oxide inclusions. Anhedral quartz occurs as a groundmass phase. Ilmenite is ubiquitous and commonly rimmed by secondary titanite. Common accessory minerals include zircon and abundant apatite.

\section{Mineral Chemistry}

\section{Feldspar}

Representative feldspar analyses are listed in Table 1. Plagioclase compositions for the mafic to intermediate rocks range from $\mathrm{An}_{20}$ to $\mathrm{An}_{73}$. Compositions are more anorthitic in the southern plutons and become more albitic in the northern plutons (Fig. 4). Phenocrysts are normally zoned with labradorite-andesine cores typically rimmed by oligoclase. Potassium feldspar $\left(\mathrm{Or}_{91-95}\right)$ is found as a primary phenocryst only in the Webhannet pluton.

\section{Pyroxene}

Pyroxene analyses are given in Table 2. Pyroxene is relatively rare and occurs only in mafic samples of the Dracut and Exeter plutons. Orthopyroxene is dominant over

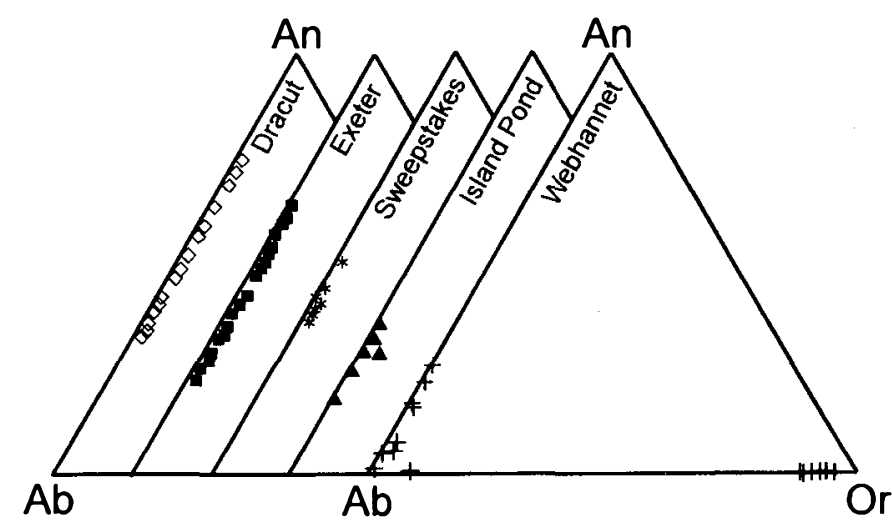

Fig. 4. Representative feldspar compositions of Merrimack belt plutons plotted on An-Ab-Or ternary diagrams.

clinopyroxene. Pyroxene grains in both plutons are slightly zoned with $\mathrm{Mg}$ - and $\mathrm{Ca}$-rich cores and $\mathrm{Fe}$-enriched rims. Pyroxene compositions are plotted in Fig. 5 and are typical of those generated in subduction-related magmas (Gill 1981).

Table 2. Representative pyroxene analyses, Merrinack Trough plutons

\begin{tabular}{|c|c|c|c|c|c|c|c|c|c|c|c|c|c|c|c|c|}
\hline & D-1.1a & D-1-2a & D-1-3a & D-1-4a & D-1-6a & D-1-8a & D-1-8a & D-1-9a & $D-4-1 a$ & $D-4-2 a$ & $D-4-3 a$ & $E-3-2 a$ & $E-3-4 a$ & $E-3-5 a$ & $E-4-1 a$ & $E-4-1 a$ \\
\hline $\mathrm{SiO}_{2}$ & 52.48 & 52.36 & 53.19 & 53.06 & 52.66 & 51.58 & 52.42 & 52.93 & 53.52 & 52.62 & 52.65 & 51.17 & 50.80 & 51.17 & 53.59 & 52.11 \\
\hline $\mathrm{TiO}_{2}$ & 0.26 & 0.19 & 0.32 & 0.16 & 0.23 & 0.60 & 0.27 & 0.29 & 0.27 & 0.33 & 0.33 & 0.19 & 0.21 & 0.15 & 0.09 & 0.35 \\
\hline $\mathrm{Al}_{2} \mathrm{O}_{3}$ & 1.18 & 1.50 & 1.49 & 1.03 & 1.07 & 2.31 & 1.39 & 1.34 & 0.97 & 1.43 & 2.03 & 0.76 & 0.67 & 0.71 & 1.16 & 2.55 \\
\hline $\mathrm{FeO}$ & 20.59 & 20.27 & 19.91 & 20.26 & 20.50 & 8.17 & 8.24 & 8.47 & 18.61 & 7.83 & 17.37 & 28.17 & 28.77 & 28.96 & 7.58 & 7.64 \\
\hline $\mathrm{MnO}$ & 0.76 & 0.60 & 0.53 & 0.59 & 0.68 & 0.29 & 0.29 & 0.30 & 0.48 & 0.33 & 0.44 & 0.80 & 0.92 & 0.65 & 0.48 & 0.33 \\
\hline $\mathrm{MgO}$ & 23.49 & 23.36 & 23.95 & 24.29 & 23.77 & 15.12 & 14.76 & 14.89 & 24.81 & 15.33 & 25.38 & 17.66 & 17.41 & 17.90 & 14.14 & 13.69 \\
\hline $\mathrm{CaO}$ & 0.79 & 1.04 & 1.06 & 0.69 & 0.84 & 20.96 & 22.09 & 21.48 & 1.16 & 21.80 & 1.43 & 1.38 & 1.21 & 0.68 & 23.62 & 22.09 \\
\hline $\mathrm{Na}_{2} \mathrm{O}$ & 0.14 & 0.09 & 0.11 & 0.10 & 0.10 & 0.48 & 0.48 & 0.47 & 0.10 & 0.32 & 0.11 & 0.10 & 0.12 & 0.06 & 0.39 & 0.51 \\
\hline Total & 99.69 & $\overline{99.41}$ & 100.56 & 100.18 & 99.85 & 99.51 & 99.94 & 100.17 & $\overline{99.92}$ & 99.99 & 99.74 & $\overline{100.23}$ & 100.11 & 100.28 & 101.05 & 99.27 \\
\hline
\end{tabular}


Table 3. Representative amphibole analyses, Merrimack Trough plutons

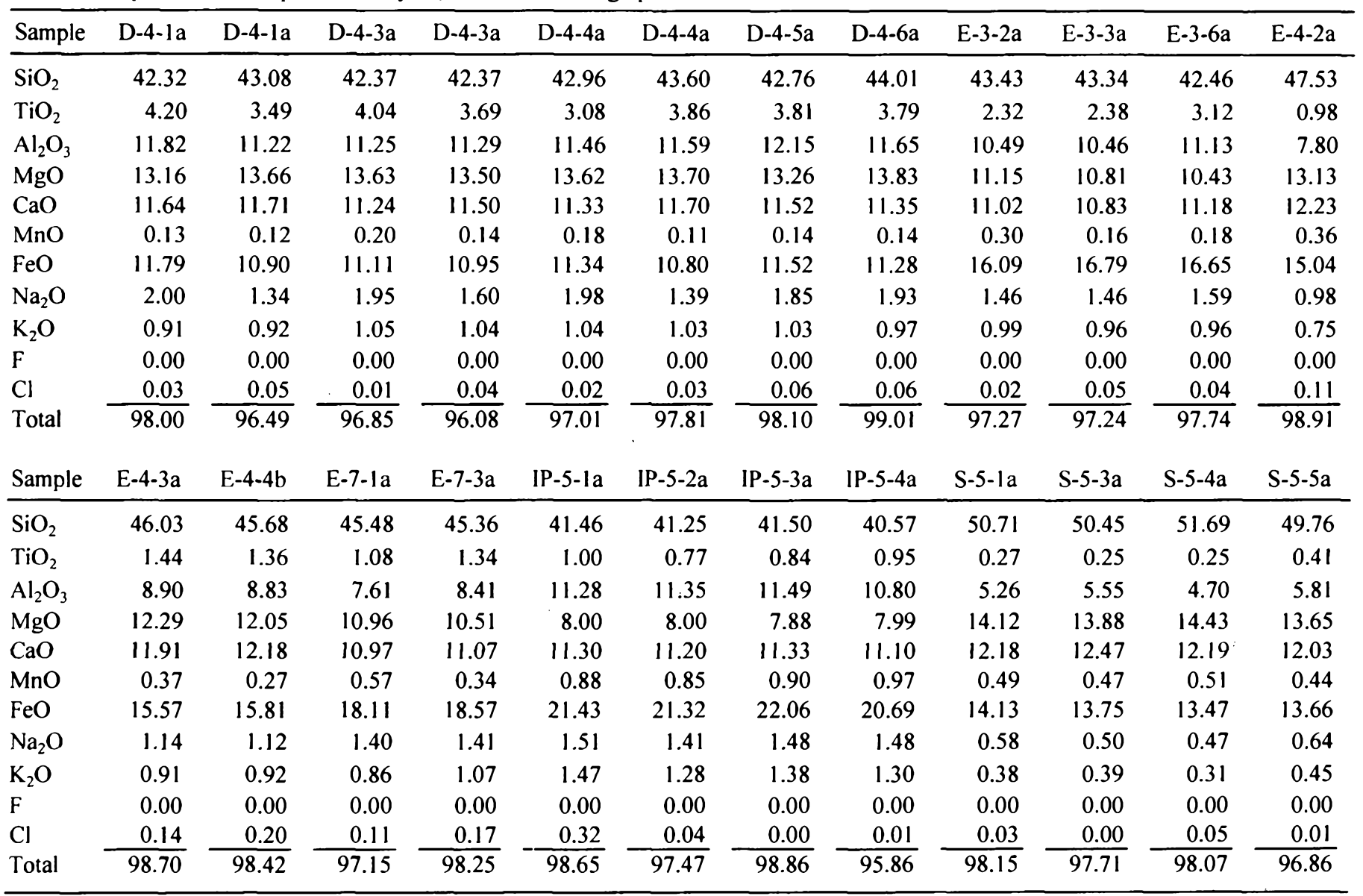

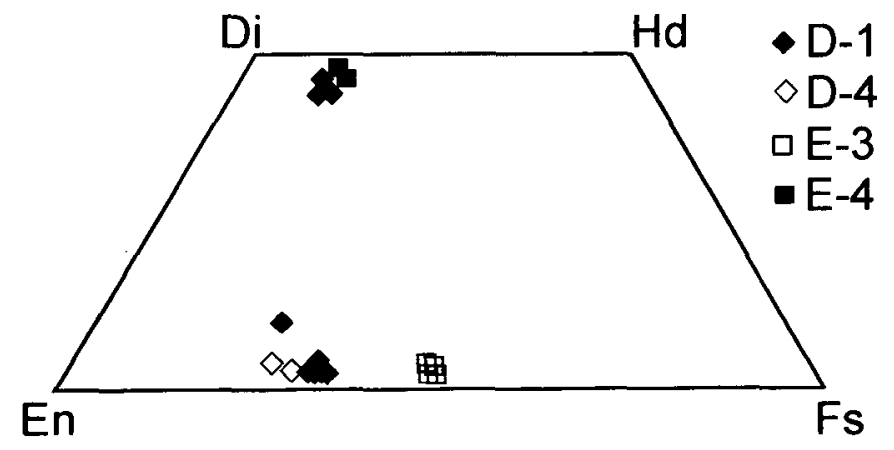

Fig. 5. Representative pyroxene compositions for Dracut (D) and Exeter (E) plutons.

Orthopyroxene compositions range from $\mathrm{Wo}_{3} \mathrm{En}_{72} \mathrm{Fs}_{25}$ to $\mathrm{Wo}_{2} \mathrm{En}_{51} \mathrm{Fs}_{47}$. Clinopyroxene compositions cluster at $\mathrm{Wo}_{46} \mathrm{En}_{43} \mathrm{Fs}_{11}$. Magmatic temperatures of $895-910^{\circ} \mathrm{C}$ were obtained from coexisting pyroxenes using two separate geothermometers (Wood and Banno 1973; Wells 1978).

\section{Amphibole}

Amphibole analyses are listed in Table 3. Amphibole compositions are plotted in Fig. 6 and form two compositional trends. Primary Ti-rich amphiboles range from magnesiohastingsite to magnesian hastingsitic hornblende (Leake 1978) and define a magmatic trend in which compositions become poorer in $\mathrm{Al}$ (total) and $\mathrm{Ti}$ at progressively higher values of $(\mathrm{Fe}+\mathrm{Mn}) /(\mathrm{Fe}+\mathrm{Mn}+\mathrm{Mg})$. A second trend defining a positive slope toward amphiboles poorer in $\mathrm{Ti}$ and $\mathrm{Al}$ at lower $\mathrm{Fe} /(\mathrm{Fe}+\mathrm{Mg})$ values and projecting away from the magmatic trend is formed by actinolitic hornblende, which suggests that it represents a secondary (sub-solidus) alteration trend. Likewise a positive correlation between $\mathrm{Al}$ (total) and $\mathrm{Ti}$ is demonstrated. The most Al- and Ti-enriched amphiboles occur in the Dracut pluton with compositions becoming poorer in both components to the north. Amphibole analyses for the Island Pond pluton show compositions richer in $\mathrm{Fe}$ and $\mathrm{Al}$ relative to magmatic amphibole from other plutons in the Merrimack belt.

\section{Biotite}

Biotite analyses are given in Table 4 plotted on Fig. 7. Biotite in the southern, more mafic plutons is richer in $\mathrm{Ti}$ and poorer in $\mathrm{Al}$ and $\mathrm{Fe}$ compared to the northern plutons. Fe and $\mathrm{Al}$ content increases in the plutons in the northern portion of the belt. Biotite analyses from the Rochester pluton reveal higher $\mathrm{Al}$ and $\mathrm{Ti}$ contents than those in the Merrimack belt plutons.

\section{Bulk ROCK Chemistry}

Although the freshest available rocks were sampled, some samples show deuteric alteration. The effects of postmagmatic alteration in samples chosen for bulk rock analyses 
a)

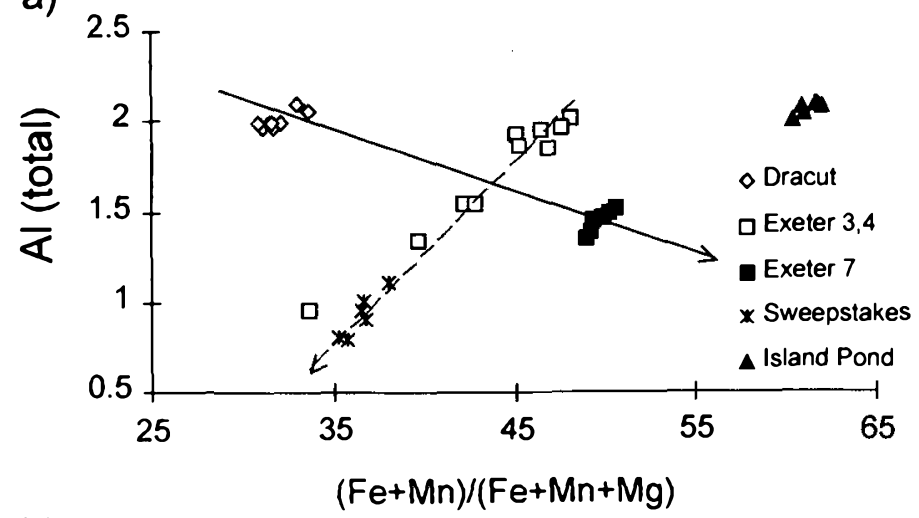

b)

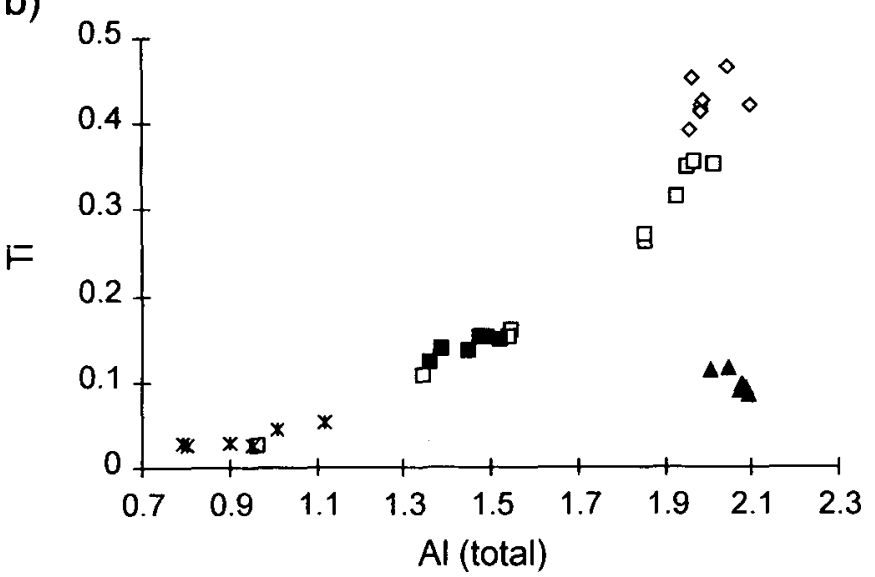

b) 0.5

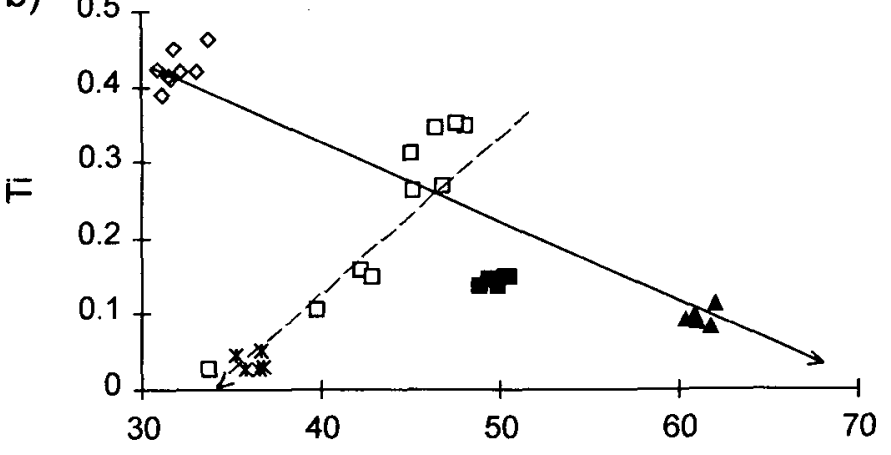

$(\mathrm{Fe}+\mathrm{Mn}) /(\mathrm{Fe}+\mathrm{Mn}+\mathrm{Mg})$
Fig. 6. a) total $\mathrm{Al}$ versus $(\mathrm{Fe}+\mathrm{Mn}) /(\mathrm{Fe}+\mathrm{Mn}+\mathrm{Mg})$; b) $\mathrm{Ti}$ versus $(\mathrm{Fe}+\mathrm{Mn}) /(\mathrm{Fe}+\mathrm{Mn}+\mathrm{Mg})$ for representative amphibole compositions of Merrimack belt and Rochester plutons. Solid arrow = magmatic trends; dashed arrow = alteration trend; and c) $\mathrm{Ti}$ versus total $\mathrm{Al}$ for representative amphibole compositions of Merrimack belt and Rochester plutons.

Table 4. Representative biotite analyses, Merrimack Trough and Rochester plutons

\begin{tabular}{|c|c|c|c|c|c|c|c|c|c|c|c|c|}
\hline Sample & D-1-1a & D-1-2a & D-1-2a & D-1-4a & $E-4-2 a$ & E-4-6a & E-7-1a & $E-7-2 a$ & IP-5-1a & IP-5-3a & IP-5-5a & IP-5-6a \\
\hline $\mathrm{SiO}_{2}$ & 36.56 & 36.40 & 36.92 & 36.52 & 35.90 & 36.60 & 36.39 & 36.11 & 35.40 & 35.82 & 35.45 & 35.22 \\
\hline $\mathrm{TiO}_{2}$ & 3.76 & 4.31 & 3.97 & 3.83 & 1.84 & 1.93 & 2.97 & 3.92 & 2.04 & 2.45 & 2.08 & 2.29 \\
\hline $\mathrm{Al}_{2} \mathrm{O}_{3}$ & 14.32 & 14.09 & 14.09 & 14.33 & 15.92 & 16.01 & 14.82 & 14.23 & 15.77 & 15.91 & 16.07 & 16.16 \\
\hline $\mathrm{MgO}$ & 15.38 & 14.96 & 14.54 & 15.09 & 12.71 & 13.49 & 10.85 & 10.53 & 10.09 & 10.05 & 9.99 & 9.74 \\
\hline $\mathrm{CaO}$ & 0.00 & 0.00 & 0.02 & 0.02 & 0.01 & 0.00 & 0.04 & 0.03 & 0.00 & 0.03 & 0.00 & 0.00 \\
\hline $\mathrm{MnO}$ & 0.08 & 0.08 & 0.12 & 0.15 & 0.25 & 0.19 & 0.23 & 0.23 & 0.70 & 0.62 & 0.61 & 0.50 \\
\hline $\mathrm{FeO}$ & 15.08 & 15.10 & 15.62 & 15.15 & 18.30 & 18.01 & 21.08 & 21.97 & 23.19 & 22.58 & 22.28 & 22.54 \\
\hline $\mathrm{Na}_{2} \mathrm{O}$ & 0.18 & 0.13 & 0.14 & 0.16 & 0.12 & 0.15 & 0.12 & 0.15 & 0.15 & 0.14 & 0.17 & 0.16 \\
\hline $\mathrm{K}_{2} \mathrm{O}$ & 9.94 & 9.81 & 10.10 & 10.03 & 9.88 & 9.80 & 9.80 & 9.78 & 9.50 & 9.62 & 9.57 & 9.58 \\
\hline $\mathrm{F}$ & 0.31 & 0.20 & 0.34 & 0.26 & 0.28 & 0.25 & 0.23 & 0.24 & 0.29 & 0.31 & 0.31 & 0.27 \\
\hline $\mathrm{Cl}$ & 0.34 & 0.30 & 0.33 & 0.31 & 0.18 & 0.14 & 0.20 & 0.18 & 0.04 & 0.02 & 0.01 & 0.03 \\
\hline Total & $\overline{95.95}$ & $\overline{95.38}$ & $\overline{96.19}$ & 95.85 & $\overline{95.39}$ & 96.57 & $\overline{96.73}$ & 97.37 & 97.17 & 97.55 & $\overline{96.54}$ & $\overline{96.49}$ \\
\hline Sample & S-5-1a & $S-5-2 a$ & S-5-3a & S-5-5a & $W-1-1 a$ & $W-1-3 a$ & $W-1-7 a$ & $W-1-8 a$ & R-4-1a & $R-4-4 a$ & $R-5-1 a$ & $R-5-3 a$ \\
\hline $\mathrm{SiO}_{2}$ & 36.24 & 36.89 & 36.18 & 36.55 & 35.52 & 35.23 & 35.96 & 35.38 & 35.45 & 34.94 & 34.89 & 34.74 \\
\hline $\mathrm{TiO}_{2}$ & 2.02 & 1.78 & 1.71 & 1.87 & 2.16 & 2.42 & 2.13 & 2.59 & 3.14 & 3.38 & 3.03 & 3.09 \\
\hline $\mathrm{Al}_{2} \mathrm{O}_{3}$ & 16.15 & 16.60 & 16.83 & 16.59 & 15.64 & 16.30 & 16.43 & 16.22 & 15.97 & 15.72 & 15.41 & 16.02 \\
\hline $\mathrm{MgO}$ & 11.84 & 12.32 & 12.17 & 12.19 & 9.05 & 7.63 & 9.41 & 7.52 & 8.52 & 8.55 & 8.71 & 8.78 \\
\hline $\mathrm{CaO}$ & 0.00 & 0.06 & 0.00 & 0.00 & 0.03 & 0.01 & 0.01 & 0.02 & 0.01 & 0.00 & 0.04 & 0.09 \\
\hline $\mathrm{MnO}$ & 0.23 & 0.30 & 0.29 & 0.29 & 0.53 & 0.38 & 0.49 & 0.46 & 0.55 & 0.59 & 0.63 & 0.56 \\
\hline $\mathrm{FeO}$ & 18.49 & 18.68 & 18.30 & 18.59 & 22.97 & 24.70 & 20.81 & 24.07 & 22.85 & 23.52 & 23.74 & 23.86 \\
\hline $\mathrm{Na}_{2} \mathrm{O}$ & 0.15 & 0.13 & 0.16 & 0.11 & 0.14 & 0.15 & 0.18 & 0.18 & 0.20 & 0.20 & 0.13 & 0.19 \\
\hline $\mathrm{K}_{2} \mathrm{O}$ & 9.73 & 9.92 & 9.99 & 9.97 & 9.54 & 9.37 & 9.61 & 9.51 & 9.51 & 9.52 & 9.47 & 9.14 \\
\hline$F$ & 0.15 & 0.21 & 0.19 & 0.19 & 0.57 & 0.57 & 0.64 & 0.55 & 0.57 & 0.59 & 0.59 & 0.54 \\
\hline $\mathrm{Cl}$ & 0.12 & 0.17 & 0.16 & 0.15 & 0.04 & 0.02 & 0.01 & 0.01 & 0.12 & 0.10 & 0.14 & 0.11 \\
\hline Total & 95.12 & 97.06 & 95.98 & 96.50 & 96.19 & $\overline{96.78}$ & 95.68 & 96.50 & 96.89 & 97.11 & 96.78 & 97.12 \\
\hline
\end{tabular}



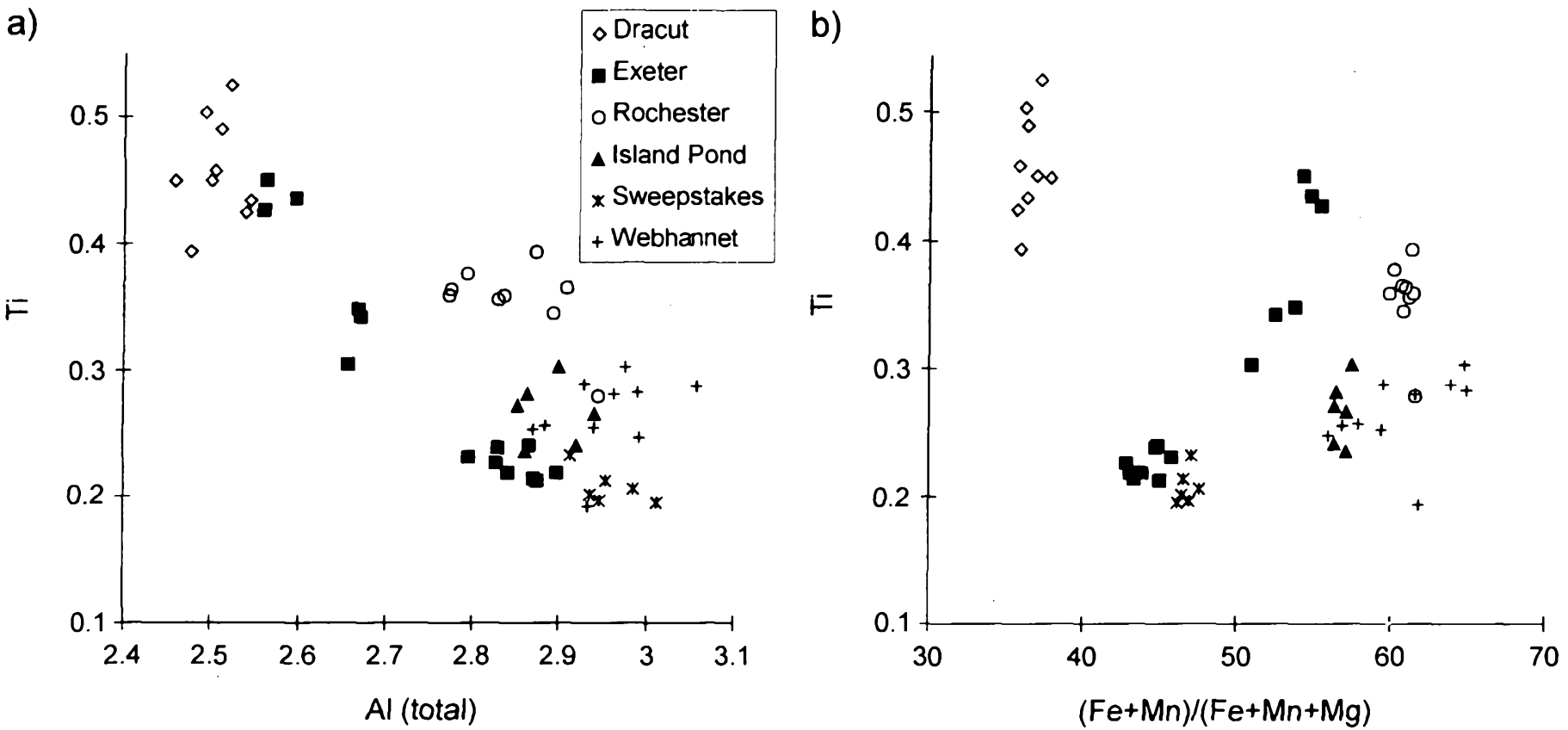

Fig. 7. a) Ti versus total $\mathrm{Al}$ and b) $\mathrm{Ti}$ versus $(\mathrm{Fe}+\mathrm{Mn}) /(\mathrm{Fe}+\mathrm{Mn}+\mathrm{Mg})$ for representative biotite compositions of Merrimack belt and Rochester plutons.

were assessed using petrographic and textural features where possible. The nature and extent of these effects varies within each pluton. Because some samples have been affected by post-emplacement alteration, mobile elements $(K, \mathrm{Na}, \mathrm{Sr}, \mathrm{Rb})$ may be less accurate indicators of original igneous chemistry and have been used with caution. Accordingly, immobile elements such as $\mathrm{Ti}, \mathrm{Zr}, \mathrm{Nb}, \mathrm{Y}, \mathrm{Ta}$, and rare earth elements were primarily used for the purpose of comparison. However, potential mobile element concentrations were considered when results are consistent on a suite scale.

\section{Major Elements}

The $\mathrm{SiO}_{2}$ contents of the six sampled plutons range from 44 to $76 \%$ and generally increases from low values in plutons in the south to higher values in the northern plutons (Table 5). $\mathrm{MgO}, \mathrm{Fe}_{2} \mathrm{O}_{3}^{\mathrm{T}}, \mathrm{CaO}, \mathrm{TiO}_{2}$, and $\mathrm{P}_{2} \mathrm{O}_{5}$ decrease systematically with increasing $\mathrm{SiO}_{2}$ content (Fig. 8a, b, c, g, h). Mg\#'s $\left[\mathrm{MgO} /\left(\mathrm{MgO}+\mathrm{FeO}^{\mathrm{T}}\right)\right]$ range from 29 to 76 and average 58 . $\mathrm{Na}_{2} \mathrm{O}$ and $\mathrm{K}_{2} \mathrm{O}$ increase broadly with increasing $\mathrm{SiO}_{2}$, and $\mathrm{Al}_{2} \mathrm{O}_{3}$ shows a slight decrease with increasing $\mathrm{SiO}_{2}$.

The plutons exhibit calc-alkaline differentiation trends on an AFM plot (not shown). Most samples fall within the medto high-K calc-alkaline fields (Fig. 8f), except for the Rochester pluton, which plots completely within the shoshonitic field. The rocks are hypersthene- and diopsidenormative with or without normative quartz and none, including the Rochester pluton, contain normative nepheline. With the exception of the Webhannet pluton, the vast majority of the plutons have low aluminum saturation indexes [mol $\left.\mathrm{Al}_{2} \mathrm{O}_{3} /\left(\mathrm{CaO}+\mathrm{Na}_{2} \mathrm{O}+\mathrm{K}_{2} \mathrm{O}\right)\right]$ or $\mathrm{A} / \mathrm{CNK}$ values $($ avg. $=0.85)$ and are metaluminous (Table 5).

Major element chemistry of the Rochester pluton contrasts with that of the Merrimack belt intrusions, especially in $\mathrm{TiO}_{2}$ and $\mathrm{P}_{2} \mathrm{O}_{5}$ (Fig. 8g, h). Significant enrichment in these elements as well as $\mathrm{K}_{2} \mathrm{O}$ (Fig. 8f) denotes its alkaline affinity and unique chemistry relative to plutons of the Merrimack belt.

\section{Trace elements}

Trace elements are listed in Tables 5 and 6 . Tectonic discrimination plots of Hf/3-Th-Ta (Fig. 9; after Wood et al. 1979) and $\mathrm{Th} / \mathrm{Yb}$ vs. $\mathrm{Ta} / \mathrm{Yb}$ (Fig. 10; after Pearce 1983) demonstrate that the magmas are subduction-related. Data for the Sharpners Pond pluton and New Hampshire Plutonic Suite are also plotted on these diagrams and indicate similar tectonic environments. Chondrite-normalized REE diagrams (after Ebihara and Anders 1982) demonstrate LREE-enriched patterns (Fig. 11). The Rochester pluton is distinctively enriched in LREE and MREE and this feature distinguishes it from plutons of the Merrimack belt. Extended element or spider diagrams exhibit patterns typical of those observed in subduction-related tectonic environments (Fig. 12; Pearce 1983). Relative to normal mid-ocean ridge basalts (NMORB), samples exhibit depletions in $\mathrm{Nb}, \mathrm{Hf}$, and $\mathrm{Ta}$, enrichment in incompatible large ion lithophile elements (LILE) such as $\mathrm{K}$, $\mathrm{Ba}, \mathrm{Th}, \mathrm{U}, \mathrm{Cs}$, and enrichment in LREE relative to heavy rare earth elements (HREE; La/ $\mathrm{Yb}_{N}=23.7$ ).

With the exception of the Rochester pluton, $\mathrm{Zr}$ and $\mathrm{Ba}$ versus $\mathrm{SiO}_{2}$ generally form coherent trends (Fig. 13a, b) showing systematic increases with increasing $\mathrm{SiO}_{2}$ and thereafter declining at $\mathrm{SiO}_{2}$ contents $>70 \%$. Samples from the Rochester pluton are anomalously enriched in $\mathrm{Ba}$ and $\mathrm{Zr}$ and plot within the same field as the Hardwick pluton of central Massachusetts (Shearer and Robinson 1988).

\section{COMPARATIVE GEOCHEMISTRY}

The major and minor element, whole-rock chemistry of the early Devonian calc-alkaline magmas of the Merrimack belt, New Hampshire Plutonic Suite, and Putnam-Nashoba 
Table 5 - Major, minor, and trace element compositions of representative samples from the Merrimack Trough and Rochester plutons

\begin{tabular}{|c|c|c|c|c|c|c|c|c|c|c|}
\hline \multirow{2}{*}{$\begin{array}{l}\text { Pluton } \\
\text { Sample } \\
\end{array}$} & \multirow{2}{*}{$\begin{array}{r}\text { Dracut } \\
\text { D-1 }\end{array}$} & \multirow[b]{2}{*}{ D-2 } & \multirow[b]{2}{*}{ D-3 } & \multirow[b]{2}{*}{ D-4 } & \multirow[b]{2}{*}{ D-6 } & \multirow[b]{2}{*}{ D-11 } & \multicolumn{3}{|c|}{ Sweepstakes } & \multirow[b]{2}{*}{ S-5 } \\
\hline & & & & & & & D-15 & $S-1$ & S-4 & \\
\hline $\mathrm{SiO}_{2}$ & 47.90 & 46.69 & 47.12 & 49.75 & 47.83 & 49.31 & 74.37 & 54.43 & 55.38 & 61.86 \\
\hline $\mathrm{TiO}_{2}$ & 2.35 & 2.96 & 2.95 & 1.04 & 2.01 & 0.98 & 0.23 & 1.07 & 0.63 & 0.80 \\
\hline $\mathrm{Al}_{2} \mathrm{O}_{3}$ & 18.29 & 18.10 & 18.06 & 16.70 & 17.25 & 17.41 & 15.24 & 18.06 & 16.88 & 17.28 \\
\hline $\mathrm{Fe}_{2} \mathrm{O}_{3}$ & 12.07 & 11.45 & 11.11 & 8.83 & 10.86 & 8.29 & 1.62 & 7.29 & 7.26 & 5.19 \\
\hline $\mathrm{MnO}$ & 0.20 & 0.19 & 0.18 & 0.17 & 0.18 & 0.16 & 0.02 & 0.15 & 0.22 & 0.10 \\
\hline $\mathrm{MgO}$ & 6.14 & 5.25 & 5.25 & 10.06 & 8.14 & 9.19 & 0.68 & 6.03 & 7.56 & 3.56 \\
\hline $\mathrm{CaO}$ & 10.73 & 10.28 & 10.54 & 10.87 & 11.30 & 11.78 & 3.26 & 7.45 & 7.98 & 5.49 \\
\hline $\mathrm{Na}_{2} \mathrm{O}$ & 2.67 & 2.75 & 2.84 & 2.12 & 1.80 & 2.09 & 4.22 & 2.84 & 2.51 & 3.15 \\
\hline $\mathrm{K}_{2} \mathrm{O}$ & 0.49 & 0.54 & 0.35 & 0.49 & 0.31 & 0.40 & 0.86 & 1.71 & 1.04 & 2.70 \\
\hline $\mathrm{P}_{2} \mathrm{O}_{5}$ & 0.47 & 0.61 & 0.59 & 0.17 & 0.16 & 0.20 & 0.04 & 0.27 & 0.11 & 0.19 \\
\hline L.O.I. & 0.48 & 1.66 & 2.16 & 1.52 & 1.22 & 1.58 & 1.15 & 1.74 & 1.67 & 0.78 \\
\hline Total & 101.79 & 100.47 & 101.14 & 101.72 & 101.06 & 101.39 & 101.70 & 101.04 & 101.25 & 101.10 \\
\hline \multicolumn{11}{|c|}{ Trace elements* } \\
\hline $\mathrm{Ba}$ & 0 & 221 & 73 & 280 & 235 & 0 & 434 & 46 & 222 & 661 \\
\hline $\mathrm{Rb}$ & 24 & 28 & 25 & 31 & 25 & 30 & 68 & 102 & 57 & 114 \\
\hline $\mathrm{Sr}$ & 559 & 582 & 610 & 647 & 650 & 694 & 469 & 398 & 584 & 376 \\
\hline $\mathrm{Zr}$ & 88 & 82 & 85 & 74 & 73 & 78 & 120 & 70 & 105 & 124 \\
\hline $\mathrm{Y}$ & 49 & 42 & 42 & 23 & 24 & 25 & 0 & 27 & 19 & 20 \\
\hline $\mathrm{Nb}$ & 31 & 33 & 33 & 18 & 25 & 18 & 0 & 14 & 11 & 8 \\
\hline $\mathrm{Sc}$ & 15 & 14 & 11 & 0 & 17 & 6 & 20 & 27 & 12 & 30 \\
\hline V & 303 & 284 & 311 & 163 & 303 & 163 & 12 & 191 & 139 & 102 \\
\hline $\mathrm{Cr}$ & 61 & 7 & 8 & 331 & 162 & 377 & 0 & 194 & 288 & 65 \\
\hline Co & 49 & 45 & 42 & 46 & 55 & 39 & 0 & 26 & 28 & 12 \\
\hline $\mathrm{Ni}$ & 10 & 7 & 1 & 44 & 19 & 32 & 1 & 24 & 20 & 21 \\
\hline $\mathrm{Cu}$ & 26 & 33 & 26 & 25 & 45 & 24 & 0 & 21 & 15 & 11 \\
\hline $\mathrm{Zn}$ & 99 & 100 & 96 & 71 & 77 & 68 & 30 & 85 & 81 & 71 \\
\hline
\end{tabular}

\begin{tabular}{|c|c|c|c|c|c|c|c|c|c|c|}
\hline $\begin{array}{l}\text { Pluton } \\
\text { Sample }\end{array}$ & S-6 & $S-11$ & S-12 & S-14 & $\begin{array}{l}\text { Island Pond } \\
\text { IP-1 }\end{array}$ & IP-2 & IP-3 & IP-5 & IP-6 & IP-7 \\
\hline $\mathrm{SiO}_{2}$ & 53.29 & 55.92 & 55.48 & 52.61 & 48.97 & 49.87 & 43.61 & 52.73 & 70.22 & 71.26 \\
\hline $\mathrm{TiO}_{2}$ & 0.50 & 1.26 & 1.40 & 0.36 & 2.18 & 2.25 & 3.54 & 1.87 & 0.40 & 0.43 \\
\hline $\mathrm{Al}_{2} \mathrm{O}_{3}$ & 22.16 & 17.25 & 16.82 & 21.10 & 17.00 & 16.83 & 14.98 & 18.80 & 16.56 & 16.45 \\
\hline $\mathrm{Fe}_{2} \mathrm{O}_{3}$ & 4.34 & 7.52 & 7.64 & 4.56 & 12.33 & 10.93 & 15.49 & 9.12 & 2.38 & 2.27 \\
\hline $\mathrm{MnO}$ & 0.07 & 0.15 & 0.15 & 0.09 & 0.28 & 0.29 & 0.30 & 0.23 & 0.04 & 0.04 \\
\hline $\mathrm{MgO}$ & 5.45 & 5.35 & 5.37 & 6.84 & 5.53 & 5.20 & 5.56 & 2.92 & 0.86 & 0.89 \\
\hline $\mathrm{CaO}$ & 10.13 & 7.38 & 7.43 & 11.66 & 9.45 & 8.61 & 9.78 & 6.38 & 2.38 & 2.23 \\
\hline $\mathrm{Na}_{2} \mathrm{O}$ & 3.31 & 2.94 & 2.86 & 2.99 & 3.14 & 3.63 & 2.96 & 4.57 & 4.74 & 4.97 \\
\hline $\mathrm{K}_{2} \mathrm{O}$ & 0.54 & 1.94 & 1.92 & 0.20 & 0.89 & 1.24 & 1.73 & 2.63 & 2.58 & 2.49 \\
\hline $\mathrm{P}_{2} \mathrm{O}_{5}$ & 0.08 & 0.23 & 0.24 & 0.03 & 0.62 & 1.03 & 2.09 & 0.77 & 0.12 & 0.26 \\
\hline L.O.l. & 0.76 & 1.36 & 0.90 & 0.87 & 0.68 & 0.81 & 0.72 & 0.59 & 0.49 & 0.58 \\
\hline Total & 100.64 & 101.30 & 100.21 & 101.32 & 101.07 & 100.69 & 100.76 & 100.61 & 100.77 & 101.87 \\
\hline \multicolumn{11}{|c|}{ Trace elements* } \\
\hline $\mathrm{Ba}$ & 349 & 168 & 286 & 47 & 560 & 760 & 426 & 1817 & 543 & 394 \\
\hline $\mathrm{Rb}$ & 42 & 79 & 78 & 36 & 69 & 65 & 53 & 63 & 155 & 164 \\
\hline $\mathrm{Sr}$ & 498 & 374 & 366 & 540 & 873 & 851 & 889 & 990 & 530 & 388 \\
\hline $\mathrm{Zr}$ & 76 & 140 & 156 & 47 & 111 & 190 & 112 & 381 & 227 & 206 \\
\hline$Y$ & 5 & 31 & 31 & 4 & 31 & 30 & 46 & 30 & 0 & 3 \\
\hline $\mathrm{Nb}$ & 3 & 17 & 17 & 3 & 22 & 20 & 38 & 26 & 0 & 0 \\
\hline Sc & 0 & 5 & 11 & 0 & 1 & 19 & 18 & 19 & 15 & 31 \\
\hline $\mathrm{V}$ & 73 & 159 & 173 & 94 & 323 & 239 & 434 & 174 & 28 & 27 \\
\hline $\mathrm{Cr}$ & 267 & 144 & 174 & 41 & 80 & 84 & 18 & 0 & 0 & 0 \\
\hline Co & 15 & 29 & 27 & 18 & 58 & 47 & 76 & 29 & 0 & 0 \\
\hline $\mathrm{Ni}$ & 41 & 6 & 10 & 26 & 67 & 32 & 8 & 0 & 0 & 0 \\
\hline $\mathrm{Cu}$ & 10 & 19 & 17 & 11 & 46 & 31 & 38 & 20 & 0 & 0 \\
\hline $\mathrm{Zn}$ & 41 & 76 & 81 & 31 & 122 & 125 & 147 & 145 & 58 & 75 \\
\hline
\end{tabular}

*Obtained by XRF 
Table 5 (continued)

\begin{tabular}{|c|c|c|c|c|c|c|c|c|c|c|c|}
\hline $\begin{array}{l}\text { Pluton } \\
\text { Sample }\end{array}$ & $\begin{array}{r}\text { Exeter } \\
\text { E-1 }\end{array}$ & E-2 & E-3 & E-4 & E-5 & E-7 & E-9 & E-11 & $\begin{array}{l}\text { Webhannet } \\
\text { W-1 }\end{array}$ & W-2 & W-3 \\
\hline $\mathrm{SiO}_{2}$ & 56.02 & 54.40 & 54.82 & 53.58 & 55.91 & 60.39 & 57.61 & 56.92 & 69.86 & 67.26 & 63.86 \\
\hline $\mathrm{TiO}_{2}$ & 0.97 & 1.09 & 0.98 & 1.14 & 1.17 & 0.97 & 1.03 & 1.08 & 0.39 & 0.58 & 0.99 \\
\hline $\mathrm{Al}_{2} \mathrm{O}_{3}$ & 14.80 & 14.75 & 14.32 & 14.84 & 16.59 & 15.68 & 15.84 & 15.57 & 15.30 & 16.63 & 15.58 \\
\hline $\mathrm{Fe}_{2} \mathrm{O}_{3}$ & 8.47 & 8.80 & 9.13 & 9.18 & 8.31 & 6.79 & 7.57 & 7.34 & 2.21 & 3.43 & 5.53 \\
\hline $\mathrm{MnO}$ & 0.17 & 0.18 & 0.18 & 0.17 & 0.16 & 0.13 & 0.15 & 0.14 & 0.05 & 0.07 & 0.11 \\
\hline $\mathrm{MgO}$ & 7.29 & 7.81 & 8.71 & 7.75 & 5.67 & 3.64 & 5.10 & 5.90 & 0.60 & 0.97 & 2.57 \\
\hline $\mathrm{CaO}$ & 7.12 & 7.47 & 7.75 & 8.54 & 7.63 & 5.63 & 6.81 & 4.94 & 1.72 & 1.92 & 3.93 \\
\hline $\mathrm{Na}_{2} \mathrm{O}$ & 2.87 & 2.69 & 2.60 & 2.30 & 2.90 & 2.96 & 2.96 & 2.94 & 3.71 & 4.14 & 3.45 \\
\hline $\mathrm{K}_{2} \mathrm{O}$ & 2.70 & 2.57 & 2.25 & 2.03 & 1.66 & 3.57 & 2.94 & 2.92 & 5.57 & 4.87 & 3.31 \\
\hline $\mathrm{P}_{2} \mathrm{O}_{5}$ & 0.27 & 0.30 & 0.27 & 0.29 & 0.26 & 0.21 & 0.28 & 0.30 & 0.12 & 0.20 & 0.34 \\
\hline L.O.I. & 0.60 & 0.52 & 0.32 & 1.31 & 1.02 & 0.50 & 0.56 & 2.63 & 0.80 & 0.65 & 1.42 \\
\hline Total & 101.29 & 100.57 & 101.33 & 101.14 & 101.28 & 100.48 & 100.85 & 100.68 & 100.33 & 100.73 & 101.09 \\
\hline \multicolumn{12}{|c|}{ Trace elements } \\
\hline $\mathrm{Ba}$ & 302 & 634 & 562 & 598 & 538 & 729 & 689 & 591 & 1262 & 1215 & 878 \\
\hline $\mathrm{Rb}$ & 25 & 31 & 26 & 29 & 68 & 79 & 78 & 76 & 134 & 120 & 102 \\
\hline $\mathrm{Sr}$ & 448 & 485 & 479 & 463 & 474 & 326 & 477 & 434 & 575 & 696 & 416 \\
\hline $\mathrm{Zr}$ & 85 & 74 & 73 & 79 & 120 & 156 & 134 & 112 & 246 & 347 & 281 \\
\hline Y & 43 & 23 & 23 & 25 & 0 & 33 & 32 & 32 & 5 & 16 & 26 \\
\hline $\mathrm{Nb}$ & 33 & 18 & 25 & 12 & 0 & 19 & 21 & 20 & 0 & 5 & 17 \\
\hline Sc & 10 & 20 & 0 & 25 & 20 & 27 & 5 & 19 & 23 & 34 & 19 \\
\hline V & 179 & 206 & 189 & 210 & 189 & 141 & 178 & 153 & 22 & 53 & 93 \\
\hline $\mathrm{Cr}$ & 376 & 390 & 467 & 335 & 188 & 101 & 182 & 245 & 0 & 0 & 51 \\
\hline Co & 34 & 38 & 40 & 41 & 33 & 21 & 26 & 26 & 0 & 0 & 17 \\
\hline $\mathrm{Ni}$ & 137 & 134 & 166 & 117 & 55 & 16 & 55 & 101 & 0 & 2 & 31 \\
\hline $\mathrm{Cu}$ & 23 & 24 & 42 & 23 & 0 & 36 & 37 & 34 & 0 & 0 & 28 \\
\hline $\mathrm{Zn}$ & 90 & 90 & 88 & 86 & 92 & 87 & 82 & 79 & 41 & 71 & 91 \\
\hline
\end{tabular}

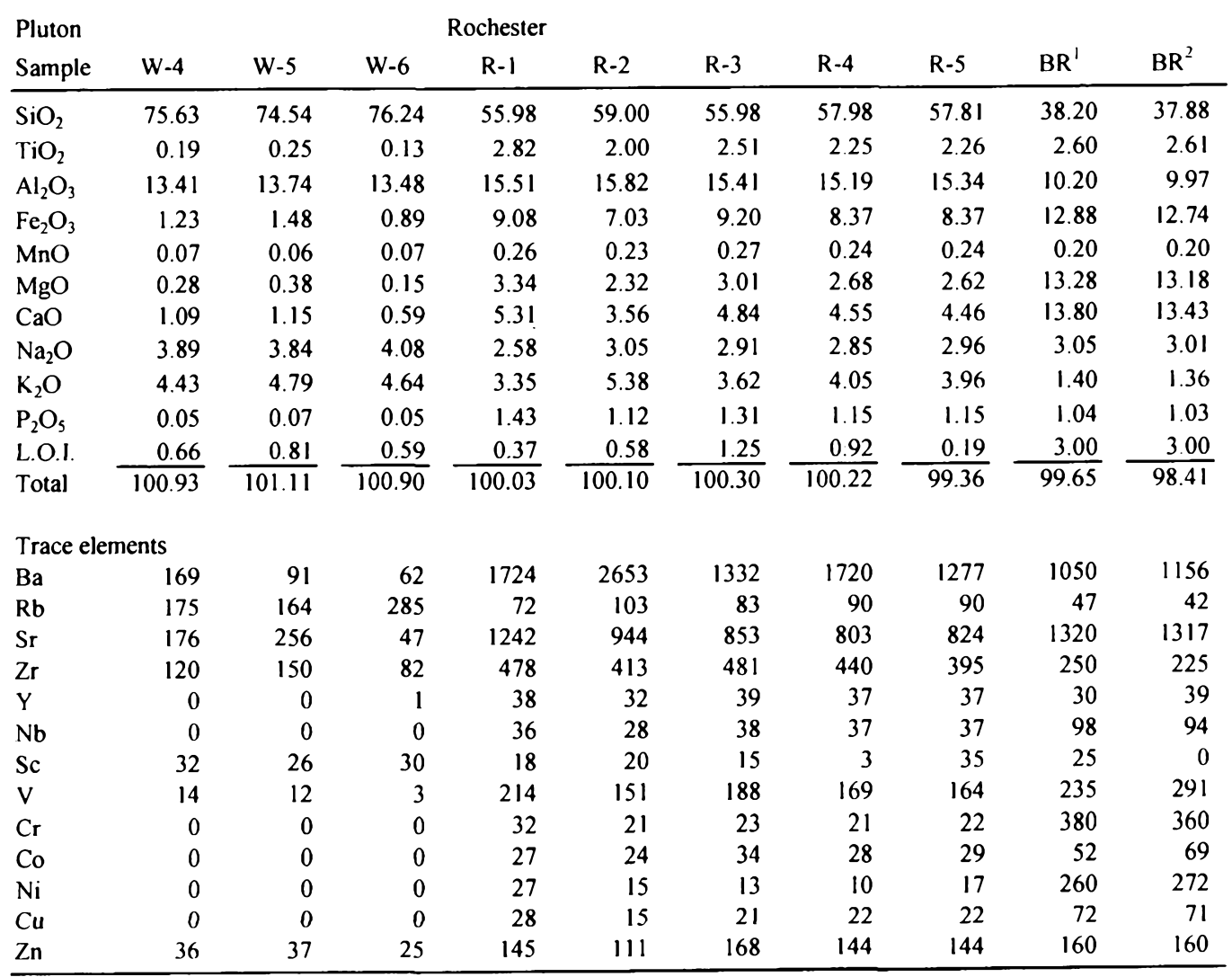

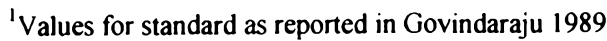

${ }^{2}$ Values for internal standard analysis 

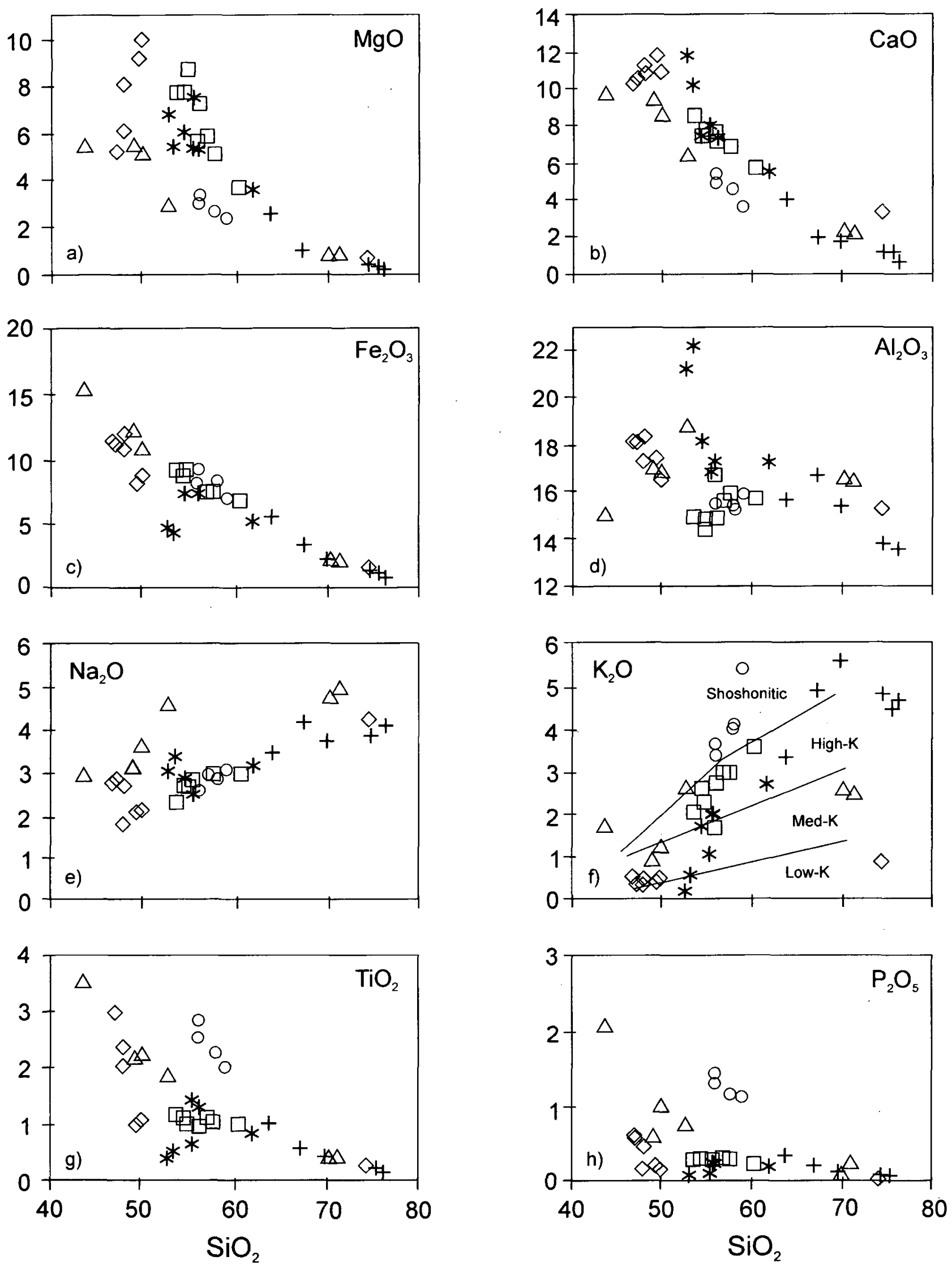

$\diamond$ Dracut $\square$ Exeter $\Delta$ Island Pond $O$ Rochester * Sweepstakes + Webhannet

Fig. 8. Harker diagrams plotting major and minor elements versus $\mathrm{SiO}_{2} . \mathrm{K}_{2} \mathrm{O}$ versus $\mathrm{SiO}_{2}$ classification fields (f) after $\mathrm{Gill}$ (1981). 
Table 6. Rare earth and selected trace element data obrained by INAA

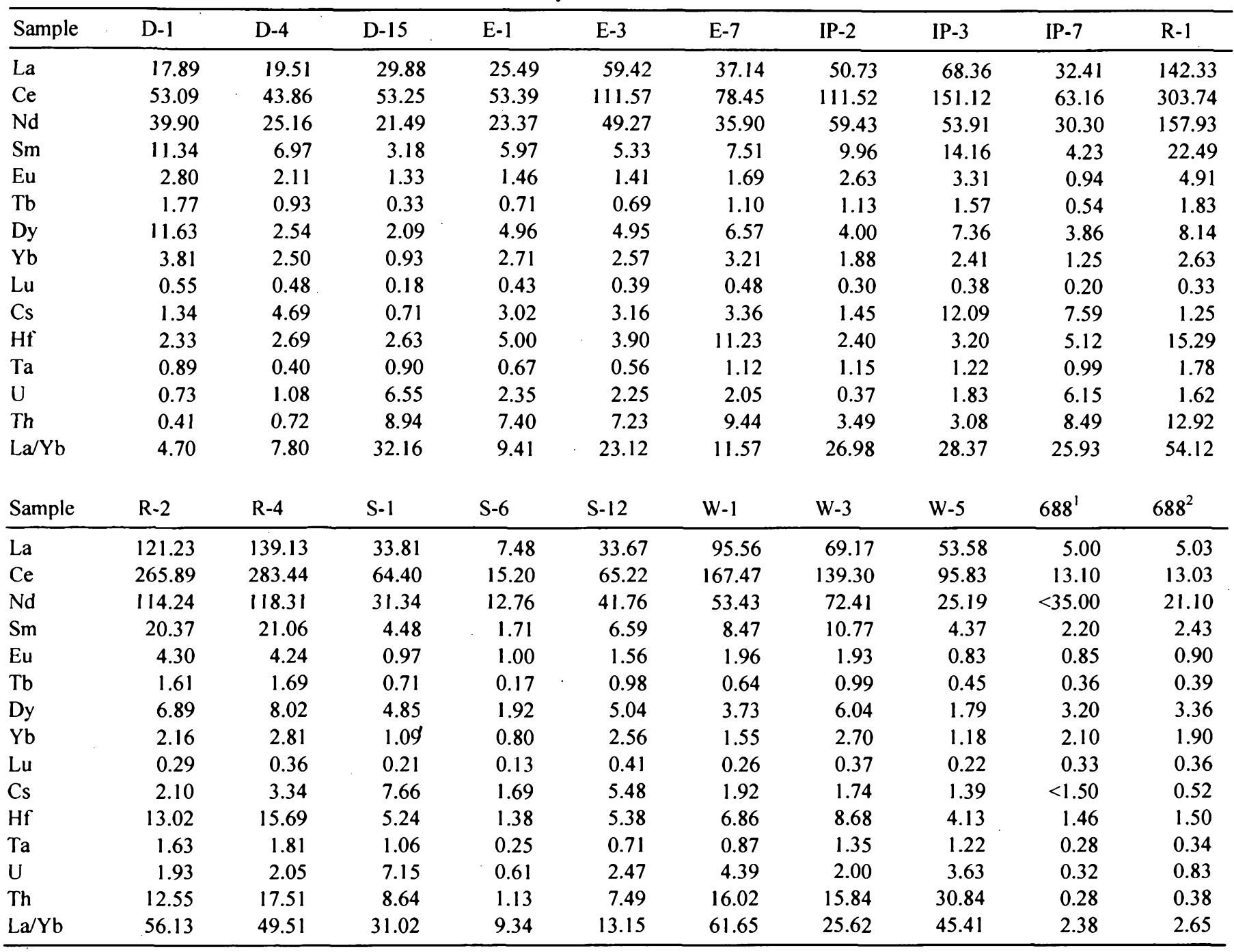

'Values for standard NIST 688 as reported in Bower 1992

${ }^{2}$ Values for analysis of internal standard NIST 688

terrane are broadly similar. Harker diagrams for most major elements and many trace elements display considerable overlap and, thus, do not distinguish the three magmatic suites from one another (not shown). Incompatible element diagrams however, show a strong correlation between the Rochester pluton and the Hardwick pluton of the Central Maine terrane (Fig. 13). $\mathrm{TiO}_{2}$ and $\mathrm{P}_{2} \mathrm{O}_{5}$ compositions of the Rochester and Hardwick plutons are very similar and clearly discriminate these plutons from the others of this study (Fig. 13c, d).

Samples from the Merrimack belt and New Hampshire Plutonic Suite span the same $\mathrm{SiO}_{2}$ range as the Sharpners Pond pluton but are enriched in $\mathrm{Sr}, \mathrm{Nb}, \mathrm{Ba}, \mathrm{Cs}, \mathrm{Th}, \mathrm{U}$, and LREE. In Fig. 14, the data define three distinct fields. Samples from the Merrimack belt and New Hampshire Plutonic Suite exhibit distinctly higher $\mathrm{Sr}$ content at a given $\mathrm{Rb}$ concentration than those of the Sharpners Pond. The Rochester and Hardwick plutons of the Central Maine terrane define a third grouping with the highest $\mathrm{Sr}$ content.

Plots of various trace element abundances and ratios for low silica samples $\left(<60 \% \mathrm{SiO}_{2}\right)$ in Figs. 15 and 16 also group the Merrimack belt and New Hampshire Plutonic Suite magmas together in a distinct field separate from those of the Sharpners Pond pluton. Plutons of the Merrimack belt and New Hampshire Plutonic Suite exhibit high concentrations of $\mathrm{Sr}, \mathrm{Ba}$, and Ta relative to the Sharpners Pond pluton (Fig. 15). The plot of $\mathrm{Th}$ vs. $\mathrm{Zr} / \mathrm{Nb}$ (Fig. 16a) distinguishes the plutons of the Merrimack belt and New Hampshire Plutonic Suite from the Sharpners Pond pluton and defines a third field for the Rochester and Hardwick Plutons. The separations observed in Fig. 16 are particularly noteworthy as $\mathrm{Ce} / \mathrm{Yb}$ and $\mathrm{Zr} / \mathrm{Nb}$ ratios are parameters least affected by postmagmatic alteration (Gill 1981). Plots of $\mathrm{Ce}, \mathrm{La} / \mathrm{Yb}$, and $\mathrm{Zr}$ vs. $\mathrm{MgO}$ in Fig. 17 illustrate the similarities in trace element compositions in the most primitive samples of the Merrimack belt and New Hampshire Plutonic Suite and show that these trends differ from those of the Sharpners Pond magmas. Plutons of the Merrimack belt and New Hampshire Plutonic Suite have similar and elevated concentrations of $\mathrm{Ce}$ and $\mathrm{La} / \mathrm{Yb}$ at the comparable $\mathrm{MgO}$ values relative to the Sharpners Pond pluton, whereas at high $\mathrm{MgO}$ concentrations, the Sharpners Pond 


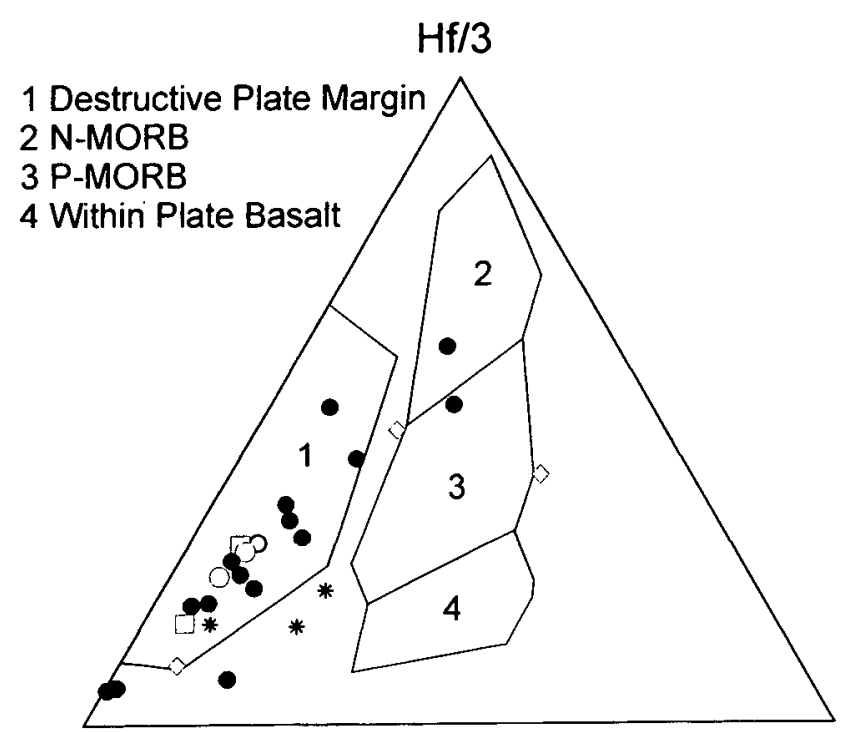

Th

Fig. 9. Hf/3 - Th - Ta tectonic discrimination diagram (after Wood et al. 1979) for representative samples of Merrimack belt (symbols as in Fig. 8) and Sharpners Pond plutons (filled circles). Data for Sharpners Pond pluton in this and subsequent Figs. from Loftenius (1988).

samples are richer in $\mathrm{Zr}$.

Chondrite-normalized REE patterns for each of the three magmatic suites further emphasize the similarities of the Merrimack belt and New Hampshire Plutonic Suite intrusions and distinguish them from the Sharpners Pond pluton (Fig. 11). Merrimack belt and New Hampshire Plutonic Suite samples show complete overlap and are characterized by higher LREE contents, steeper LREE/HREE slopes, and negligible to slightly negative $\mathrm{Eu}$ anomalies compared to the relatively flat LREE/HREE slopes of the Sharpners Pond pluton. N-MORB normalized extended element diagrams (Sun and McDonough 1989) for the three suites display similar shaped patterns indicative of a subduction-related arc environment (Fig. 12). The plutons of the Merrimack belt and New Hampshire Plutonic Suite are remarkably similar and enriched in LILE, LREE, and Ta relative to the Sharpners Pond Diorite. The Rochester Pluton shows significant enrichment in all of the aforementioned elements and is unlike all other plutons considered.

\section{Discussion}

The recognition of suites, supersuites, and superunits of plutons within large magmatic and tectonic provinces on the basis of geochemical features (Larsen 1948; Cobbing et al. 1977; White et al. 1977; Bateman 1983) was a significant advancement in assessing igneous processes. A suite, supersuite, or superunit is a temporally and spatially related set of plutons that are fundamentally related and considered to be major assemblages of consanguineous rocks (Pitcher 1985; Atherton and Sanderson 1985). Wyborn et al. (1987), for example, defined the Boggy Plain Supersuite based upon its distinctly higher concentration of $\mathrm{K}, \mathrm{Ba}, \mathrm{Sr}, \mathrm{Rb}, \mathrm{La}, \mathrm{Ce}, \mathrm{U}$,

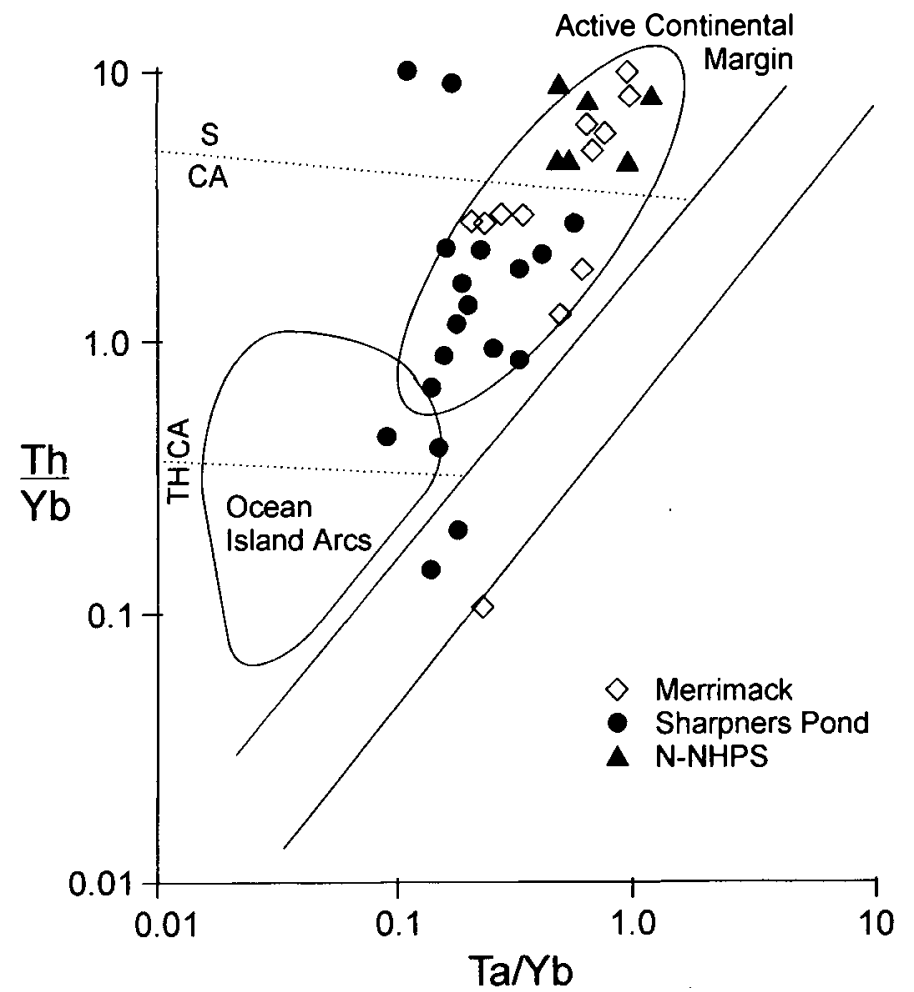

Fig. 10. $\mathrm{Th} / \mathrm{Yb}$ versus $\mathrm{Ta} / \mathrm{Yb}$ tectonic discrimination diagram (after Pearce 1983) showing representative samples of Merrimack belt, New Hampshire Plutonic Suite (data in this and subsequent Figs. from Dorais and Paige 2000; Nulhegan pluton from Ayuso and Arth 1992). $\mathrm{TH}=$ tholeiitic; $\mathrm{CA}=$ calc-alkaline; $\mathrm{S}=$ shoshonitic.

and Th relative to other I-type suites in the Lachlan Fold Belt. The application of the suite concept has also been beneficial in tectonic investigations where it has been used in the identification and correlation of discrete tectonic terranes (Chappell et al. 1988; Heatherington 1996; Kerr 1997; Barr and Kerr 1997). Similarly, a geochemical evaluation of magmas of the Merrimack belt, New Hampshire Plutonic Suite, and Sharpners Pond pluton enables an assessment of the suite concept and an evaluation of the tectonic relationship of the lithotectonic zones that host these plutons.

Major, trace, and rare earth element data for the intrusions of the Merrimack belt and New Hampshire Plutonic Suite are remarkably similar. Based on the criteria of suite/supersuite/super-unit determination (e.g., Cobbing et al. 1977), these geochemical similarities suggest that plutons of the Merrimack belt and New Hampshire Plutonic Suite belong to the same suite. This interpretation is consistent with that of Lyons et al. (1997) who, rather than following Billings (1956) in classifying the Merrimack belt magmas as the distinct Hillsborough Plutonic Series, grouped the Devonian plutons of the Merrimack belt with the New Hampshire Plutonic Suite on the basis of age. The implication of the magmas belonging to a common suite is that the New Hampshire Plutonic Suite and Merrimack belt plutons formed within the same magmatic arc. If the New Hampshire Plutonic Suite and Merrimack belt plutons do indeed represent a single suite, this requires that the rocks these magmas intruded (i.e. the metasedimentary rocks of the Merrimack belt and Central Maine terrane) were adjacent to each other or continuous at the time of magmatism 
a)

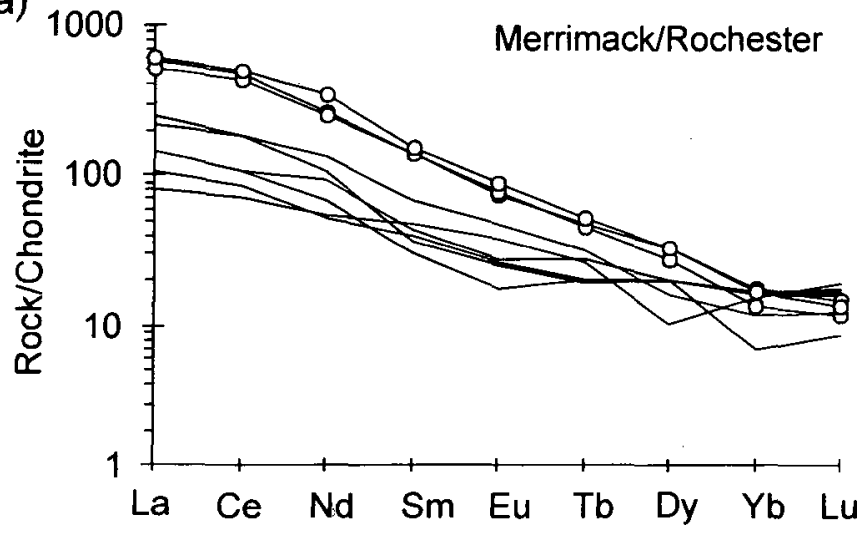

c)

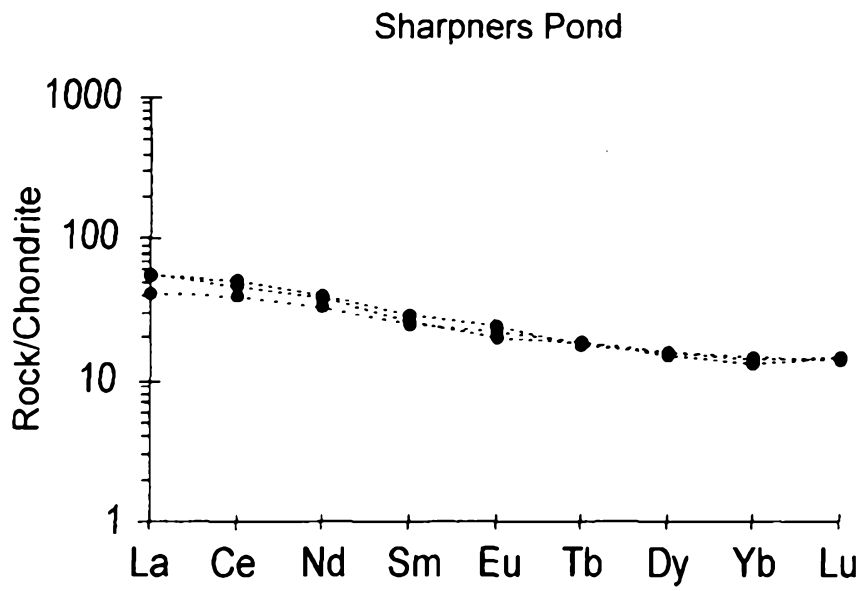

b)

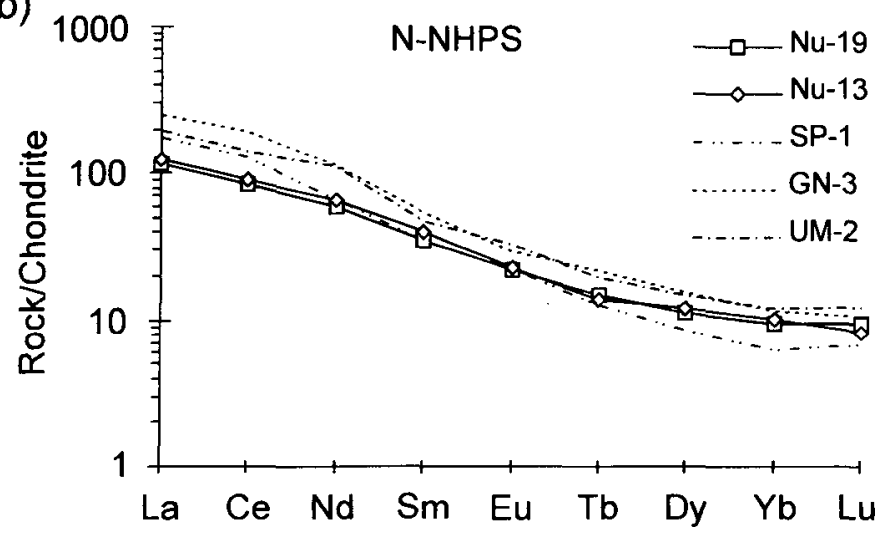

d)

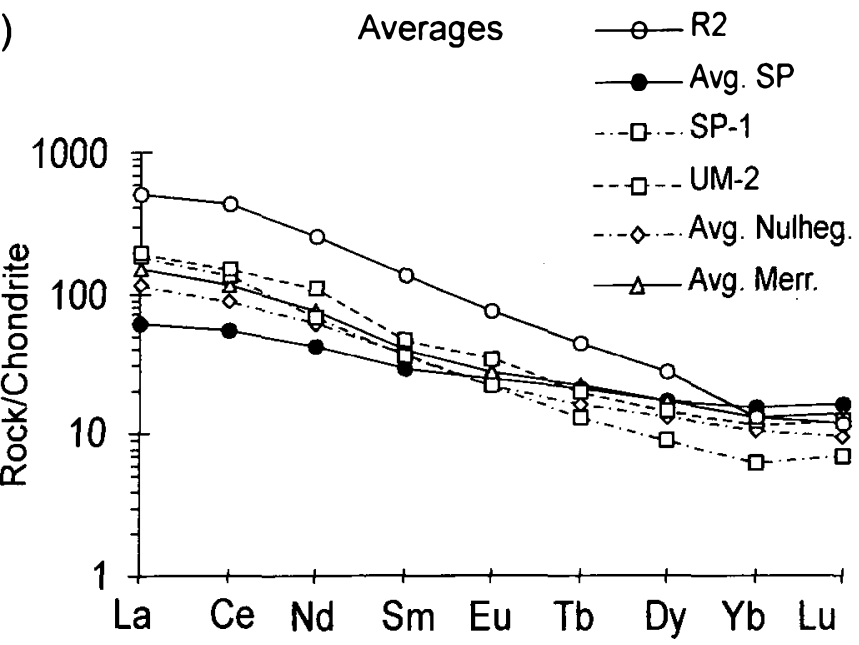

Fig. 11. Chondrite-normalized REE patterns for: a) Merrimack belt (solid lines) and Rochester plutons (lines with circles); b) Northern New Hampshire Plutonic Suite; and c) Sharpners Pond pluton. The Rochester samples are enriched in REE whereas the Sharpners Pond pluton is REE poor compared to all other plutons. The Merrimack belt plutons are identical in REE concentrations to those of the New Hampshire Plutonic Suite. d) Averages of the Rochester (R-2), Merrimack belt, Nulhegan (New Hampshire Plutonic Suite), and Sharpners Pond (Ave SP) samples are plotted along with individual samples of the Spider Lake (SP-1) and Umbagog (UM-2) plutons (New Hampshire Plutonic Suite). Normalization constants of Anders and Ebihara (1982).

( $400 \mathrm{Ma}$, Fig. 4b), an interpretation also presented by Rankin (1994).

Although these data alone provide no information concerning the genetic relations of the metasedimentary rocks of the Central Maine terrane and Merrimack belt, other workers have considered the Merrimack belt and Central Maine terrane as equivalent on a lithostratigraphic basis (Billings 1956; Osberg 1980; Robinson et al. 1998; Bothner and Hussey 1999). Our data suggest that regardless of whether the Merrimack belt and the Central Maine terrane are indeed the same lithotectonic unit that was severed by the Norumbega fault system, or if they are different lithotectonic zones now juxtaposed across the faults, the two lithotectonic zones must have been contiguous during emplacement of the New Hampshire Plutonic Suite.

The Sharpners Pond pluton is similar in overall composition and tectonic setting to those of the New Hampshire Plutonic Suite and Merrimack belt, but has distinct trace element characteristics. Of particular significance is the contrast in trace element abundances observed in the most primitive samples from each suite. If magmas have different compositions in the earliest stages of their evolution (highest
$\mathrm{MgO}$ contents, Fig. 17), it is likely they had unique parental magmas and are genetically distinct. Subtle differences in selected trace element abundances (Fig. 17), particularly in the most primitive samples, suggest that the Sharpners Pond pluton is genetically unrelated to the Merrimack belt and New Hampshire Plutonic Suite plutons.

Subduction of oceanic lithosphere was a prominent tectonic mechanism in the formation of the Appalachian orogen. The quantity, location, and polarity of subduction zones in the Late Silurian and Early Devonian however, remain highly contentious issues. The presence of two northeast-trending volcanic belts on either side of the Central Maine terrane and the Merrimack belt suggests the presence of one or more subduction zones, but the interpretation of these rocks remains equivocal. Bradley (1983) and Ludman et al. (1993) interpreted the Piscataquis volcanic belt of northern New England and southern Canada as arc volcanic rocks generated by northwest-dipping subduction beneath North America. Likewise, the Silurian Frontenac rift of Moench (1993) has been interpreted as a back-arc rifting related to northwestward subduction. Several workers (McKerrow and Ziegler 1971; Bradley 1983; Ludman et al. 1993) have 
a)

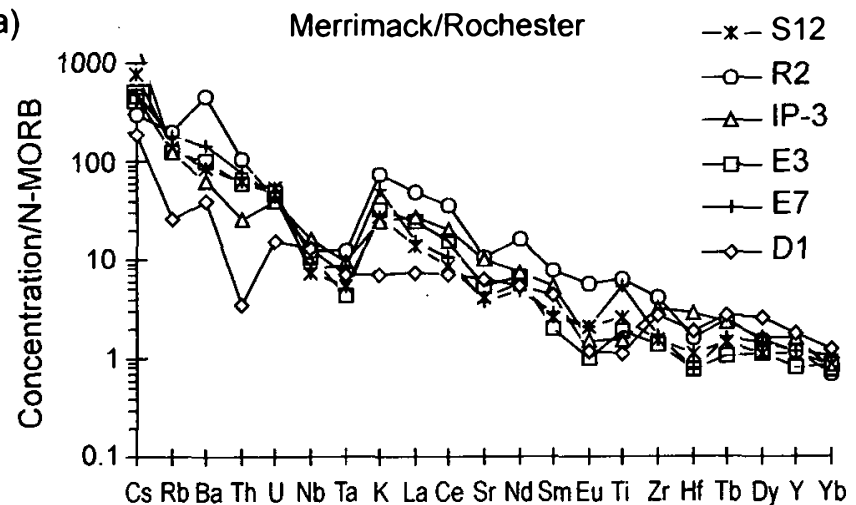

c)

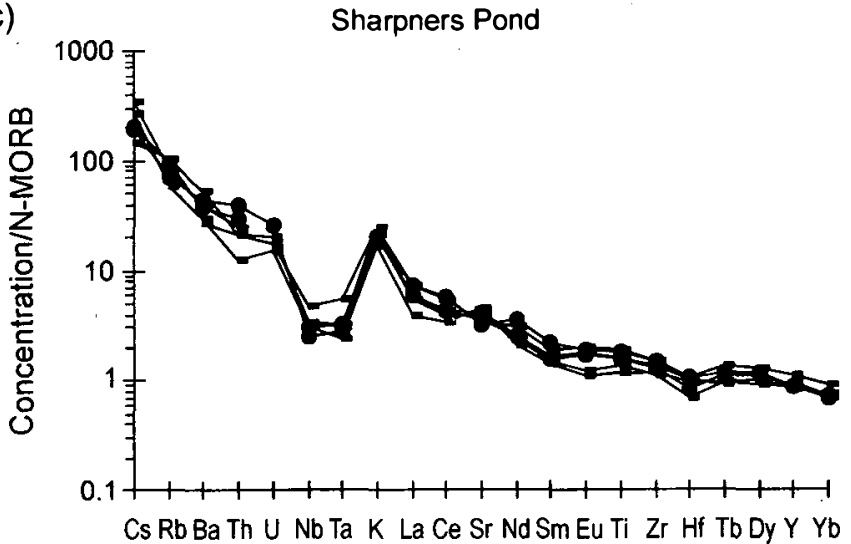

b)

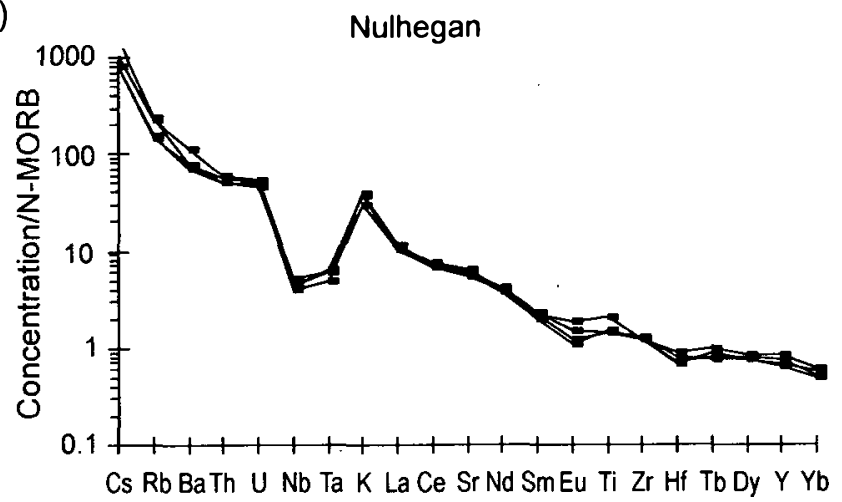

d)

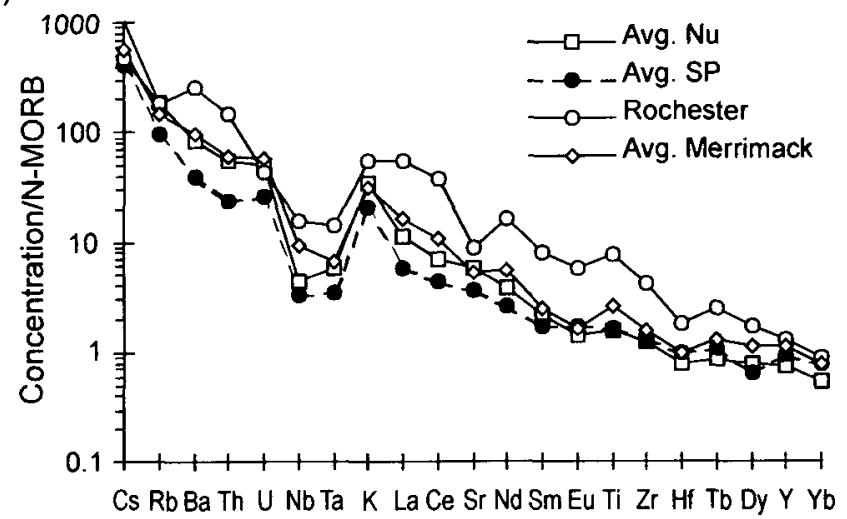

Fig. 12. N-MORB normalized extended REE diagrams for samples of: a) the Merrimack and Rochester plutons; b) the Nulhegan pluton (New Hampshire Plutonic Suite); c) the Sharpners Pond pluton; d) average of each suite. The Rochester pluton is enriched in the majority of plotted elements and stands apart from all other plutons (a complete data set of the Hardwick pluton is not available). The Sharpners Pond pluton is poor in these elements compared to the Nulhegan pluton and Merrimack belt samples, which are identical.

suggested the Late Silurian-Early Devonian Coastal volcanic belt of eastern New England originated from eastward dipping subduction beneath the western margin of impinging Avalon. Other researchers (McKerrow and Ziegler 1971; Bradley 1983; Ludman et al. 1993; Acaster and Bickford 1999) have speculated that the Merrimack belt $( \pm$ the Central Maine terrane) was a closing ensialic basin in the Late Silurian-Early Devonian with both the eastern and western margins subducting beneath Avalon and North America, respectively. Modern analogs of this tectonic setting however, such as the Mollocca Sea collision zone, are scarce (Hamilton 1978; Moore et al. 1981).

Across-arc variations in the chemistry of magmas formed in subduction zones are well established (i.e., Gill 1981; Tatsumi and Eggins 1995) and can be useful for deciphering subduction polarity in ancient arcs where other lines of evidence are absent. Systematic variations include an increase in the concentration of incompatible elements such as $\mathrm{K}$, the LILE, and LREE with increasing distance above the subduction zone. On the basis of such relations, Hepburn et al. (1995) suggested that the west to east sequence of the Sharpners Pond pluton of Putnam-Nashoba and the Cape Anne Complex of the Avalon terrane are an expression of eastward subduction beneath these lithotectonic zones (Fig. 4c). They inferred that the Dracut and Exeter plutons in the
Merrimack belt are the western most expressions of that subduction zone. However, the increase in LILE and LREE concentrations from Sharpners Pond pluton in the east to the Merrimack belt magmas to the west argues against this scenario (Figs. 11 and 12). If the Sharpners Pond pluton and Cape Anne Complex do in fact represent an eastward dipping subduction zone, the enrichment in incompatible elements in the plutons of the Merrimack belt relative to the Sharpners Pond pluton indicate that the these two magmatic suites could not have formed within the same arc. The geochemical similarities between plutons of the Merrimack belt and the New Hampshire Plutonic Suite leads us to suggest that the Merrimack belt magmas resulted from the same westwarddipping subduction zone that produced the mafic to intermediate composition magmas of the New Hampshire Plutonic Suite (Bradley 1983; Ludman et al. 1993). Subsequent to the emplacement of the Merrimack belt plutons, the Merrimack belt may have been laterally transposed by Acadian and/or Alleganian dextral movement along the Norumbega fault system (Ludman et al. 1999; West 1999).

The Rochester Pluton is chemically distinct from all other sampled plutons and remarkably similar to the $360 \pm 1 \mathrm{Ma}$ Hardwick Tonalite located in the Central Maine terrane of north-central Massachusetts. This geochemical correlation suggests the possibility of a $\sim 360 \mathrm{Ma}$ age for the Rochester 
a)

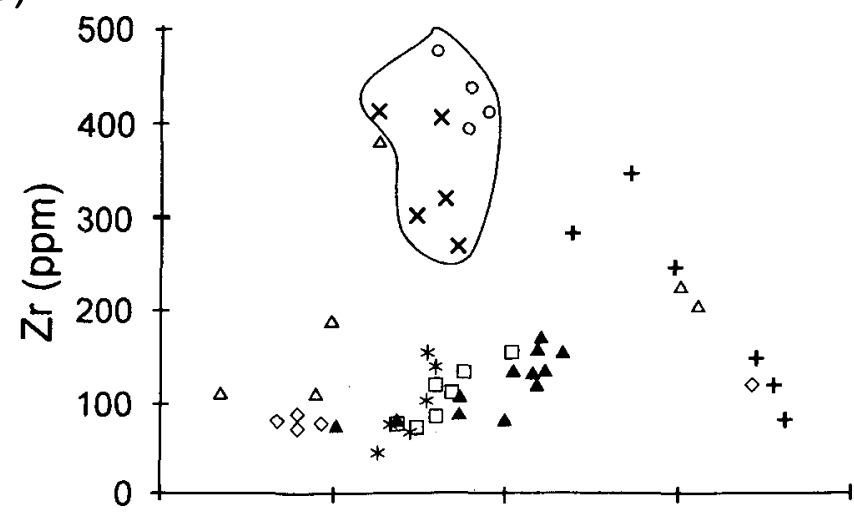

c)

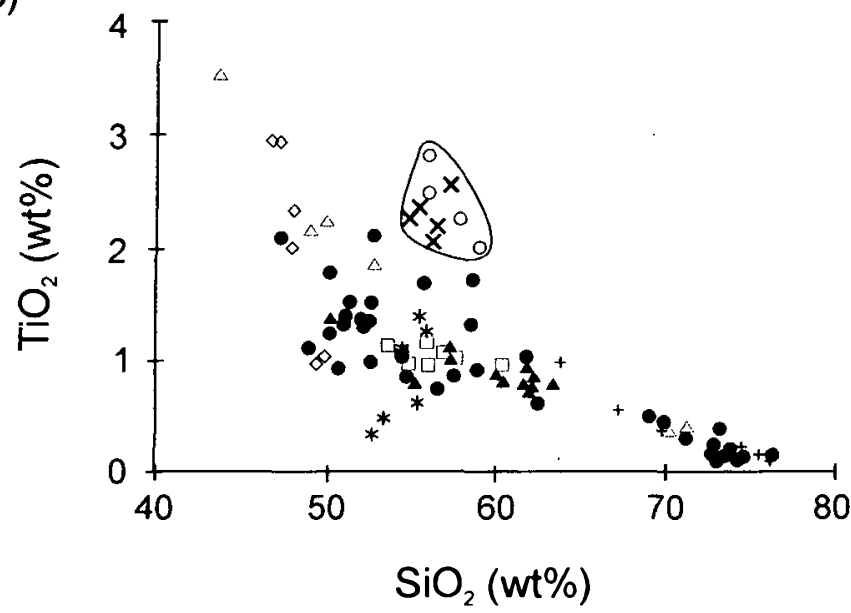

b)

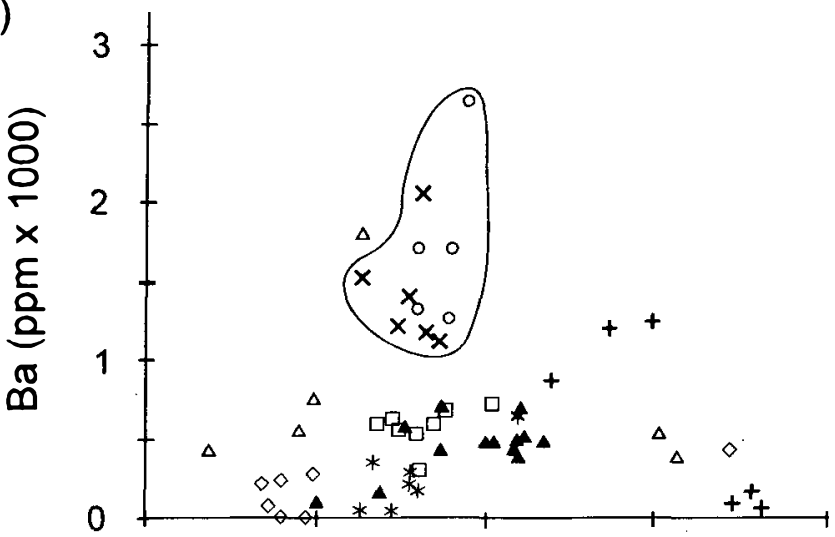

d)

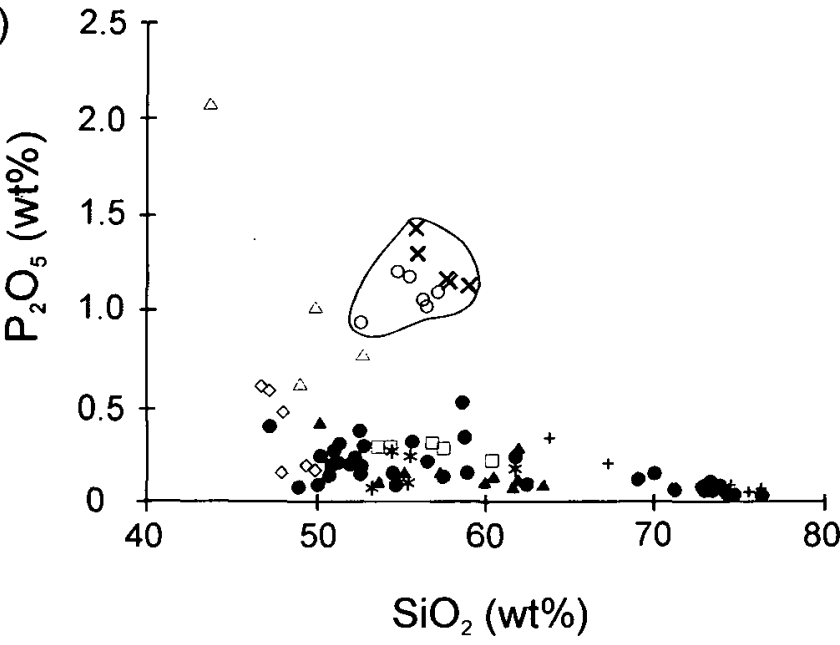

Fig. 13. a) $\mathrm{Zr}$ versus $\mathrm{SiO}_{2}$; b) $\mathrm{Ba}$ versus $\mathrm{SiO}_{2}$; c) $\mathrm{TiO}_{2}$ versus $\mathrm{SiO}_{2}$; and d) $\mathrm{P}_{2} \mathrm{O}_{5}$ versus $\mathrm{SiO}_{2}$ diagrams for samples of the Merrimack belt, New Hamphsire Plutonic Suite, Rochester and Hardwick plutons (data for the Hardwick pluton in this and subsequent Figs. are from Shearer and Robinson 1988). The Merrimack belt and the selected relatively mafic New Hampshire Plutonic Suite plutons are identical in composition. Note that the Rochester and Hardwick plutons are identical and are rich in $\mathrm{Zr}, \mathrm{Ba}, \mathrm{TiO}_{2}$ and $\mathrm{P}_{2} \mathrm{O}_{5}$ at equivalent $\mathrm{SiO}_{2}$ values compared to rocks of both the New Hampshire Plutonic Suite and the Merrimack belt plutons. Symbols are as in previous diagrams.

pluton. Furthermore, the alkaline affinity of the Rochester and Hardwick plutons may help constrain the polarity of subduction that gave rise to the magmas of the New Hampshire Plutonic Suite and Merrimack belt. The occurrence of alkaline magmas in back-arc, typically extensional, tectonic settings is well documented. Hole (1988) postulated that postsubduction alkaline magmas might retain a subduction zone geochemical signature up to $40 \mathrm{Ma}$ subsequent to subduction. If the Rochester and Hardwick plutons represent back-arc magmatism relative to the mafic New Hampshire Plutonic Suite in Vermont, Maine, and New Hampshire, it would imply that subduction was initiated west of the Central Maine terrane and dipped to the southeast.

Two alternative interpretations of the Rochester and Hardwick plutons are possible: (1) these plutons may be the expression of back-arc magmatism associated with subduction unrelated to the New Hampshire Plutonic Suite; or (2) the Rochester and Hardwick plutons could be the result of extensional tectonics induced by the oblique collision of the Avalon with the eastern margin of North America. Given the lack of evidence for the former hypotheses and the presence of intense ductile deformation indicative of considerable

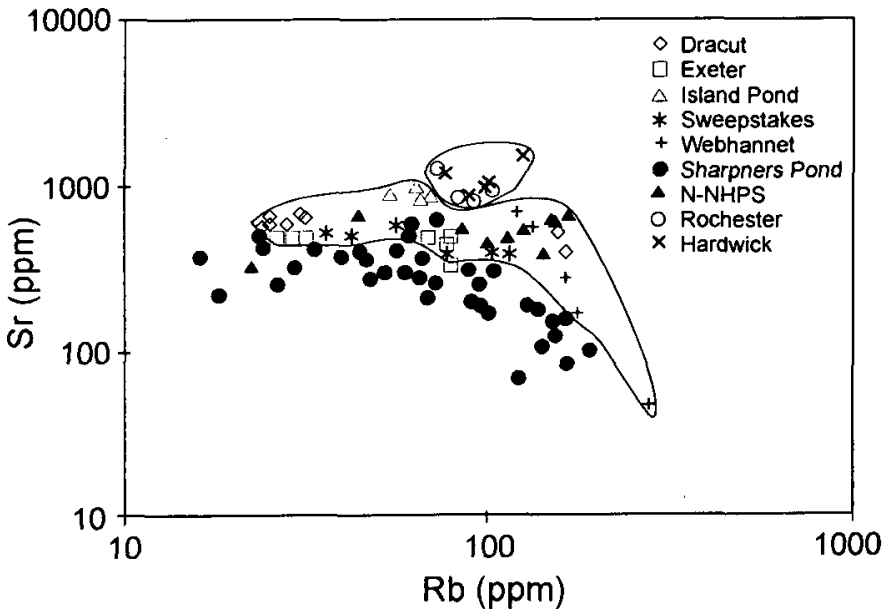

Fig. 14. Sr vs. Rb diagram for the Merrimack belt, the New Hampshire Plutonic Suite (N-NHPS), the Sharpners Pond, Rochester, and Hardwich plutons. The New Hampshire Plutonic Suite and Merrimack belt plutons are identical in composition. The Sharpners Pond samples are poorer in $\mathrm{Sr}$ at equivalent values of $\mathrm{Rb}$ compared to those of the Merrimack belt and New Hampshire Plutonic Suite. The Rochester and Hardwick samples are again identical in composition, plotting at higher $\mathrm{Sr}$ values than the other samnles. 
a)

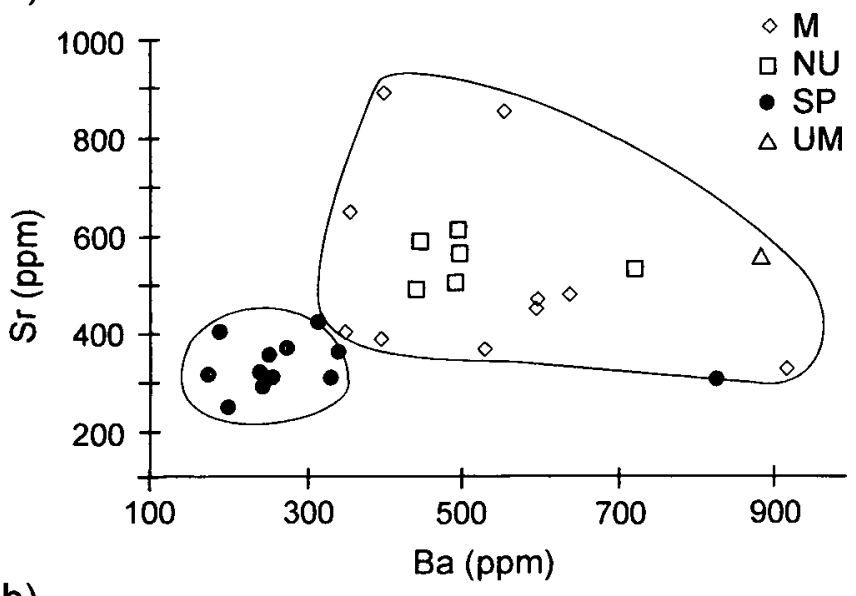

b)

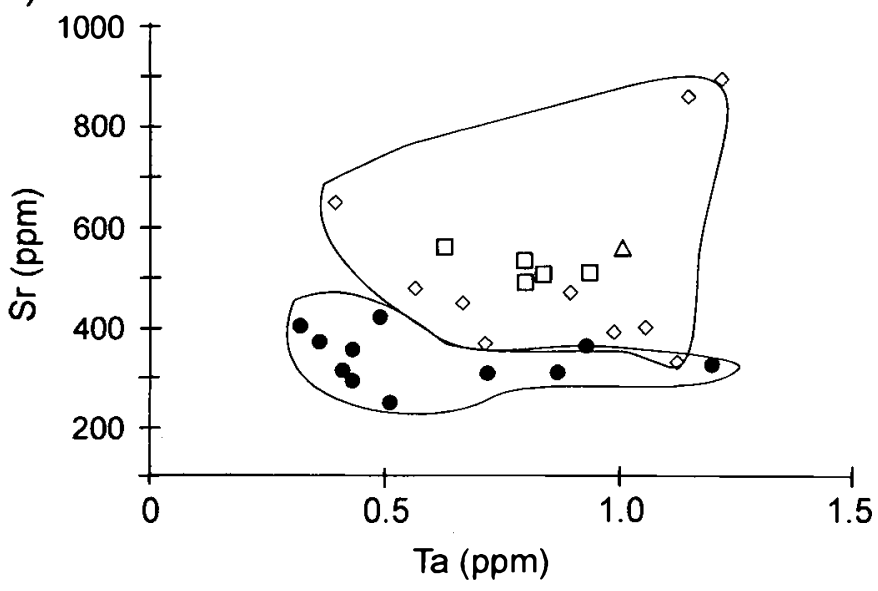

Fig. 15. a) $\mathrm{Sr}$ vs. $\mathrm{Ba}$ and b) $\mathrm{Sr}$ vs. Ta diagrams for samples from the Merrimack belt (M), Nulhegan (NU), Umbagog (UM), and Sharpners Pond (SP) plutons. The Merrimack belt and New Hampshire Plutonic Suite samples (NU and UM) plot within the same fields. In contrast, the Sharpners Pond samples are distinct from those of the Merrimack belt and New Hampshire Plutonic Suite.

tangential forces in this portion of the Central Maine terrane (Robinson et al. 1998), we favour a westward subduction model generating the mafic magmas of the New Hampshire Plutonic Suite and Merrimack belt with transpressive extension to account for the Rochester/Hardwick plutons. The geochemical signature of subduction such as bulk-rock negative $\mathrm{Nb}$ and $\mathrm{Ta}$ anomalies in the Rochester and Hardwick plutons were likely inherited from the underlying mantle which retained the metasomatic signature of Early Devonian subduction. The Keweenawan Rift represents an ancient example of such collision-induced rifting. Gordon and Hempton (1986) proposed that the Keweenawan Rift and associated magmatism developed in pull apart basins in response to continent-continent convergence of the Grenville Orogeny.

\section{Conclusions}

The Early Devonian plutons of the Merrimack belt represent a suite of calc-alkaline, subduction-related magmas. Similarities in age and composition of the Merrimack belt a)

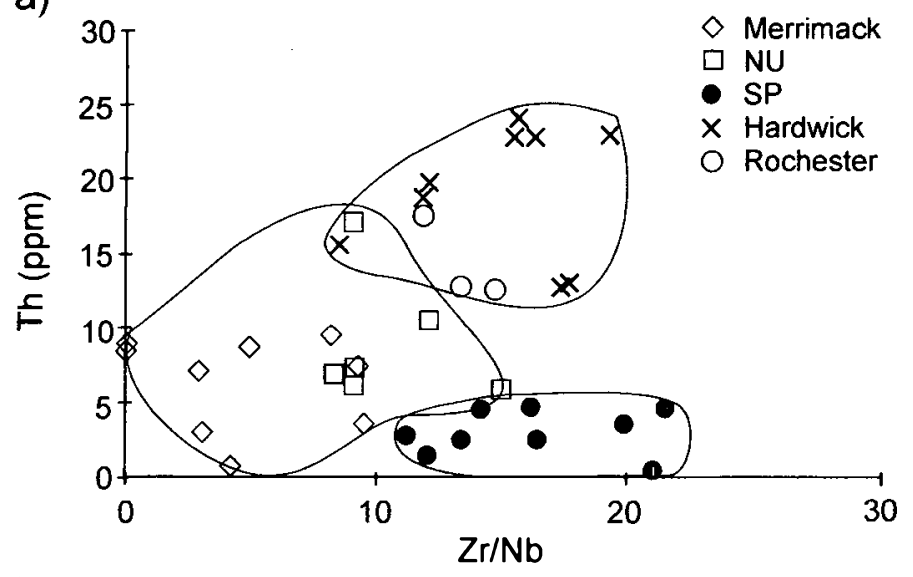

b)

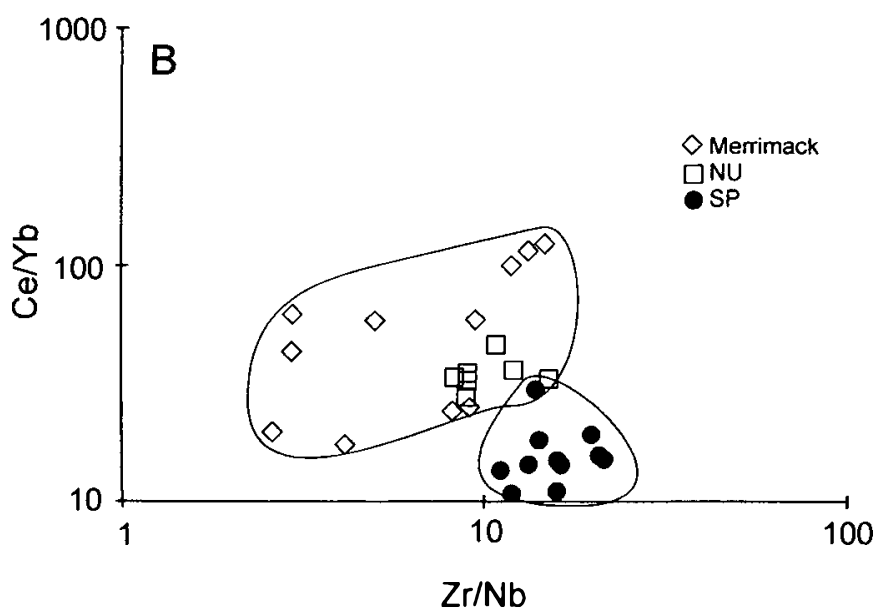

Fig. 16 a). Th versus $\mathrm{Zr} / \mathrm{Nb}$ diagram for Merrimack belt, Nulhegan (NU), Sharpners Pond (SP), Rochester, and Hardwick plutons. The Merrimack belt and the Nulhegan pluton of the New Hampshire Plutonic Suite plot in the same field. The Rochester and Hardwick plutons are likewise identical whereas the Sharpners Pond samples plot in a distinct field. $\mathrm{b}$ ). $\mathrm{Ce} / \mathrm{Yb}$ versus $\mathrm{Zr} / \mathrm{Nb}$ diagram showing that the Merrimack belt and the Nulhegan pluton of the New Hampshire Plutonic Suite plot in the same field. As above, the Sharpners Pond samples plot in a field that is distinct from the other samples.

magmas and the New Hampshire Plutonic Suite suggest that both were emplaced within a common arc and define a single magmatic suite. This correlation also implies a North American affinity for the Merrimack belt, as it would be required to have been adjacent to the Central Maine terrane at the time of emplacement (Fig. 3b). Given that the Central Maine terrane and the Merrimack belt are currently separated by a major ductile shear zone, the notion that these two lithotectonic zones were along strike at the time of magmatic emplacement and subsequently juxtaposed to their current configuration is likely. The Sharpners Pond pluton has distinct trace element characteristics and defines a second subductionrelated suite that was generated in a separate arc.

Marked geochemical similarities between the Rochester Pluton and Hardwick Tonalite suggest both a genetic relationship and a possible age of $\sim 360$ Ma for the former intrusion. The Rochester pluton has alkaline affinities while retaining calc-alkaline signatures. Although the Hardwick and 
perhaps Rochester plutons are 40 Ma younger than the dated mafic magmas of the New Hampshire Plutonic Suite and Merrimack belt, they may be expressions of back-arc rifting. If so, this indicates that the subducting lithosphere dipped eastward beneath the presently juxtaposed Central Maine terrane and Merrimack belt. Alternatively, our preferred interpretation is that these plutons formed in a pull-apart rifting environment resulting from oblique accretion of the Avalon terrane to the North American margin. The $360 \mathrm{Ma}$ age of the Hardwick (and presumably the Rochester) pluton and high-grade metamorphism in north-central Massachusetts and southeast New Hampshire is enigmatic as it post-dates the Early Devonian onset of the Acadian Orogeny by 40-50 million years. Thus, the setting of this protracted magmatic activity and its relation to previous Acadian magmatism requires additional investigation.

\section{ACKNOWLEDGEMENTS}

We thank Jim Brophy for an earlier review of the paper and David West and David Gibson for helpful journal reviews. We also thank David McMullin for assistance with the illustrations. This study was supported by NSF grants EAR9418203 to Wintsch and EAR-9909410 to Wintsch and Dorais.

\section{REFERENCES}

ACASTER, M., \& BICKFORD, M.E. 1999. Geochronology and geochemistry of Putnam-Nashoba terrane metavolcanic and plutonic rocks, eastern Massachusetts: Constraints on the early Paleozoic evolution of eastern North America. Geological Society of America Bulletin, 111, pp. 240-253.

AleinikofF, J.N., Walter, M., \& FanNing, C.M. 1995. U-Pb ages of zircon, monazite, and sphene, from rocks of the Massabesic Gneiss Complex and Berwick Formation, New Hampshire and Massachusetts. Geological Society of America, Abstracts with Programs, 27, p. 26.

Armstrong, T.R., Tracy, R.J., \& Hames, W.E. 1992. Contrasting styles of Taconian, Eastern Acadian and Western Acadian metamorphism, central and western New England. Journal of Metamorphic Geology, 10, pp. 415-426.

ATHERTON, M.P., \& SANDERSON, L.M. 1985. The chemical variation and evolution of the super-units of the segmented Coastal batholith. In Magmatism at a Plate Edge. Edited by W.S. Pitcher, M.P. Atherton, E.J. Cobbing, and R.D. Beckinsdale. Blackie and Son, pp. 208-227.

AYUSO, R.A., \& ARTH, J.G. 1992. The Northeast Kingdom batholith, Vermont: magmatic evolution and geochemical constraints on the origin of Acadian granitic rocks. Contributions to Mineralogy and Petrology, 111, pp. 1-23.

BARR, S.M., \& KerR, A. 1997. Late Precambrian plutons in the Avalon terrane of New Brunswick, Nova Scotia, and Newfoundland. Geological Society of America Memoir 191, pp. 45-74.

BATEMAN, P.C. 1983. A summary of critical relations in the central part of the Sierra Nevada batholith, California, U.S.A. In Circum-Pacific Plutonic Terranes. Edited by J.A. Roddick. Geological Society of America, Memoir 159, pp. 241-254.

BILlings, M. P. 1956. The Geology of New Hampshire, Part 2, Bedrock Geology. New Hampshire State Planning and Development Commission. Concord, N.H., 203 p.

Bothner, W.A., Gaudette, E.L., Fargo, T.G., Bowring, S.A., \&
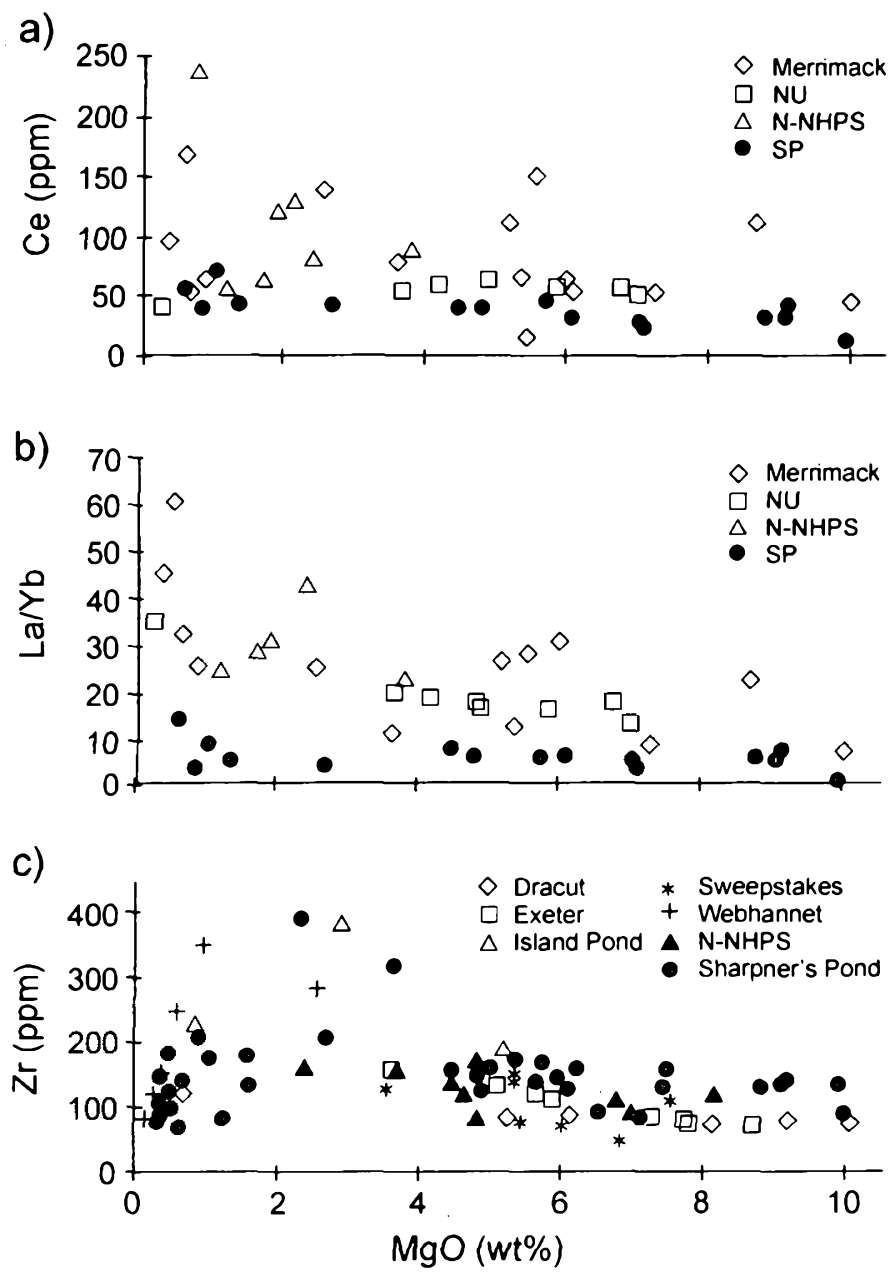

Fig. 17. a) Ce vs. $\mathrm{MgO}$, b) $\mathrm{La} / \mathrm{Yb}$ vs. $\mathrm{MgO}$ and c) $\mathrm{Zr}$ versus $\mathrm{MgO}$ diagrams for samples of the Merrimack belt. New Hampshire Plutonic Suite, and Sharpners Pond plutons. The most primitive magmas of the Merrimack belt and New Hampshire Plutonic Suite have similar $\mathrm{Ce}$. $\mathrm{La} / \mathrm{Yb}$, and $\mathrm{Zr}$ values, suggesting similar parental magmas. These values are different than those of the most primitive Sharpners Pond samples, suggesting each was derived from a different suite of magmas.

ISACHSEN, S.E. 1993. Zircon and sphene U/Pb ages of the Exeter Pluton: Constraints on the Merrimack Group and part of the Avalon Composite Terrane. Geological Society of America, Abstracts with Programs, 25, p. 183.

BOTHNER, W.A., \& HUSSEY, A.M., II 1999. Norumbega connections: Casco Bay, Maine, to Massachusetts? In Norumbega Fault System of the Northern Appalachians. Edited by A. Ludman and D.B. West Jr. Geological Society of America, Special Publication 331, pp. 59-72.

Bothner, W.A., Boudette, E.L., Fagan, T.J., Gaudette, H.E., LAIRD, J., \& OLSZEWSKI, W.J., JR. 1984. Geologic framework of the Massabesic anticlinorium and the Merrimack trough, southeastern New Hampshire. In Geology of the Coastal Lowlands: Boston, MA to Kennebunkport, Maine. Edited by L. Hanson. 76th Annual Meeting, New England Intercollegiate Geological Conference, pp. 186-206.

BOWER. N.W., LEWIS, C.M., \& NEIFERT, P.E. 1992. Elemental concentrations in twenty NIST standards of geochemical interest. Geostandards Newsletter, 16, pp. 27-40.

BRADLEY, D.C. 1983. Tectonics of the Acadian orogeny in New England and adjacent Canada. Journal of Geology, 91, pp. 381- 
400.

Chappell, B.W., White, A.J.R., \& Hine, R. 1988. Granite provinces and basement terranes in the Lachlan Fold Belt, southeastern Australia. Australian Journal of Earth Sciences. 35, pp. 505521.

Cobbing, E.J., Pitcher, W.S., \& TAYlOR, W.P. 1977. Segments and super-units in the Coastal batholith of Peru. Journal of Geology, 85, pp. 625-631.

DAllmeyer, R.D., BlackwOOD, R.F., \& ODOM, A.L. 1981. Age and origin of the Dover fault: Tectonic boundary between the Gander and Avalon zones of the northeastern Newfoundland Appalachians. Canadian Journal of Earth Sciences, 8, pp. 14311442.

DENNEN, W.H. 1943. A nickel deposit near Dracut, Massachusetts. Economic Geology, 38, pp. 25-55.

DORAIS, M.J., PAIGE, M.L. 2000. Regional mineralogic, geochemical and isotopic variations of northern New England plutons: Implications for magma sources and Grenville - Avalon basement terrane boundaries. Geological Society of America Bulletin, 112, pp. 900-914.

EbINHARA M., \& ANDERS E. 1982. Solar-system abundances of the elements. Geochimica et Cosmochimica Acta, 46, pp. 2363 2380.

ENGLUND, E.J. 1976. The bedrock geology of the Holderness quadrangle, New Hampshire. N.H. Department of Resources and Economic Development, Bulletin 7, 90 p.

EUSDEN, J.D., JR., \& BARRIERO, B. 1988. The timing of peak highgrade metamorphism in central-eastern New England. Maritime Sediments and Atlantic Geology, 24, pp. 241-255.

EUSDEN, J.D., JR., \& LYONS, J.B. 1993. The sequence of Acadian deformations in central New Hampshire. Geological Society of America, Special Paper 275, pp. 51-65.

Gaudette, H.E., Kovach, A., \& HusSey, A.M. 1982. Ages of some intrusive rocks of southwestern Maine, U.S.A. Canadian Journal of Earth Sciences, 19, pp. 1350-1357.

GaudetTe, H.E., Bothner, W.A., LAIRD, J., Olszewski, W.J., JR., \& Cheatham, M.M. 1984. Late Precambrian/Early Paleozoic deformation and metamorphism in southeastern New Hampshire - Confirmation of an exotic terrane. Geological Society of America, Abstracts with Programs, 16, p. 516.

GILL, J.B. 1981. Orogenic andesites and plate tectonics. New York: Springer-Verlag. $390 \mathrm{p}$.

GolDSMITH, R. 1991. Stratigraphy of the Nashoba Zone, eastern Massachusetts: An enigmatic terrane. United States Geological Survey Professional Paper 1366-F, 22 p.

GORDON, M.B., \& HEMPTON, M.R. 1986. Collision-induced rifting: The Grenville Orogeny and the Keweenawan rift of North America. Tectonophysics, 127, pp. 1-25.

GovindaraJu, K. 1989. Compilation of working values and sample description for 272 geostandards. Geostandards Newsletter, 13, pp. 1-113.

GriffiN, T.J., White, A.J.R., \& ChapPell, B.W. 1978. The Moruya batholith and geochemical contrasts between the Moruya and Jindabyne suites. Journal of the Geological Society of Australia, 25, pp. 235-47

HAMILTON, W. 1978. Tectonics of the Indonesian region. United States Geological Survey Professional Paper 1078, 345 p.

HATCH N.L., MOENCH, R.H., \& LYONS, J.B. 1983. Silurian - Lower Devonian stratigraphy of eastern and south-central New Hampshire. American Journal of Science, 283, pp. 739-761.

HATCHER, R.D., JR. 1989. Tectonic synthesis of the U.S. Appalachians, In The Appalachian-Ouachita orogen in the United States (The Geology of North America, v. F-2). Edited by R.D. Hatcher Jr., W.A. Thomas and G.W. Viele. Boulder, CO, Geological Society of America, pp. 511-536.

Heatherington, A.L., Mueller, P.A., \& Nutman, A.P. 1996. Neoproterozoic magmatism in the Suwannee terrane:
Implications for terrane correlation. Geological Society of America, Special Paper 304, pp. 257-268.

HePburn, J.C., DunNing, G.R., \& Hon, R. 1995. Geochronology and regional tectonics implications of Silurian deformation in the Nashoba terrane, southeastern New England, U.S.A. In Current Perspectives in the Appalachian-Caledonian Orogen. Edited by J.P. Hibbard, C.R. van Staal and P.A. Cawood. Geological Association of Canada, Special Paper 41, pp. 349-366.

HolE, M.J. 1988. Post-Subduction alkaline volcanism along the Antarctic Peninsula. Journal of the Geological Society, London, 145, pp. 985-998.

HON, R., HEPBURN, J.C., BOTHNER, W.A., OlSZEWSKI, W.J., Gaudette, H.E., Dennen, W.H., \& Loftenius, C. 1986. MidPaleozoic calc-alkaline rocks of the Nashoba Block and Merrimack trough. In Guidebook for Field trips in Southwestern Mine. Edited by D.W. Newberg. New England Intercollegiate Geological Conference, 78th Annual Meeting, Bates College, Lewiston, ME, pp. 37-52.

Hon, R., Paige, M.L., \& Loftenius, C.J. 1993. Petrogenesis of two diverse mid-Paleozoic complexes of eastern Massachusetts: Atype Cape Anne Granite and I-type Sharpners Pond Quartz Diorite. In Field Trip Guidebook for the Northeastern United States: 1993 Boston GSA. Edited by J.T. Cheney and J.C. Hepburn. Department of Geology and Geography, University of Massachusetts, Amherst, MA, 2, pp. Q1-Q28.

HuSSEY, A.M., II 1962. The geology of southern York County, Maine. Maine Geological Survey, Special Studies Series, 4, pp. $1-67$.

HusSey, A.M. II, \& BothNeR, W.A. 1993. Geology of the Coastal Lithotectonic Belt - SW Maine and SE New Hampshire. In Field Trip Guidebook for the Northeastern United States: 1993 Boston 1993. Edited by J.T. Cheney and J.C. Hepburn. Department of Geology and Geography, University of Massachusetts, Amherst, MA, 1, pp. 1891-1901

HuSSEY, A.M., II, BothNeR, W.A., \& ThOMPSON, J.A. 1986. Geological comparisons across the Norumbega fault zone, southwestern Maine. In Guidebook for Field Trips in Southwestern Maine. Edited by D.W. Newburg. New England Intercollegiate Geological Conference, $78^{\text {th }}$ Annual Meeting, Bates College, Lewiston, ME, pp. 53-78.

KERR, A. 1997. Space-time composition relationships and Appalachian-cycle plutonic suites in Newfoundland. Geological Society of America Memoir 191, pp. 193-220.

LARSEN, E.S. 1948. Batholith and associated rocks of Corona, Elsinore and San Luis Rey quadrangles, southern California. Geological Society of America Memoir, 29, $182 \mathrm{pp}$.

LEAKE, B.E. 1978. The nomenclature of amphiboles. Canadian Mineralogist, 16, pp. 501-520.

LOFTENIUS, C.J. 1988. The geochemistry and the petrogenesis of the Sharpners Pond Plutonic Suite, NE Massachusetts [MS thesis]. Boston College. 284 pp.

LudMan, A., HoPECK, J.P, \& Brock, P.C. 1993. Nature of the Acadian Orogeny in eastern Maine. In The Acadian Orogeny: Recent studies in New England, Maratime Canada, and the Autochthonous Foreland. Edited by D.C. Roy and R.W. Skehan. Geological Society of America, Special Paper 275, pp. 67-84.

Ludman, A., LanzirotTl, A., LuX, D., \& ChunzenG, W. 1999. Constraints on timing and displacement of multistage shearing in the Norumbega fault system, eastern Maine. In Norumbega Fault System of the Northern Appalachians. Edited by A. Ludman and D.J. West Jr. Geological Society of America, Special Paper 331, pp. 179-194.

LyONS, J.B., BOUDETTE, E.L., \& ALEINIKOFF, J.N. 1982. The Avalonian and gander zones in central eastern New England. In Major Structural zones and faults of the northern Appalachians. Edited by P. St. Julien and J. Beland. Geological Association of Canada, Special Paper 24, pp. 43-66. 
LYONS, J.B., BOTHNER, W.A., MOENSCH, R.H., \& THOMPSON, J.B., JR. 1997. Bedrock geologic map of New Hampshire.

MCKERROW, W.S., \& ZIEGLER, A.M. 1971. The Lower Silurian paleogeography of New Brunswick and adjacent terranes. Journal of Geology, 79, pp. 635-646.

MOENCH, R.H. 1993. Highlights of metamorphic stratigraphy and tectonics in western Maine and northeastern Vermon. In Field trip guidebook for the northeastern United States: 1993 Boston GSA. Edited by J.T. Cheney and J.C. Hepburn. Department of Geology and Geography, University of Massachusetts, Amherst, MA, Contribution No. 67, pp. DD.1-DD.32.

MOENCH, R.H., \& PANKIWSKYl, K.A. 1988. Geologic map of western interior Maine. United States Geological Survey Miscellaneous Map 1-1692.

Moore, G.F., Kadarisman, D., Evans, C.A., \& Hawkins, J.W. 1981. Geology of the Taluad Islands, Molucca Sea collision zone, northeast Indonesia. Journal of Structural Geology, 3, pp. $467-475$.

Nielson, D.L. 1981. The bedrock geology of the Hillsboro quadrangle, New Hampshrire. N.H. Department of Resources and Economic Development, Bulletin 8, 76 p.

Nielson, R.L., LANDIS, E.S., CECI, V.M., \& POSTON, C.J. 1989. The commingling of diverse magma types in the Flagstaff Lake igneous complex. In Studies in Maine Geology. Edited by R.D. Tucker and R.G. Marvinney. 3, pp. 67-78.

Olszewski, W.J., \& GaudeTte, H.E. 1988. Early Paleozoic thermotectoinc histroy of eastern New England: CambroOrdovician metamorphism and plutonism - a distinct featrue of the "Casco" terrane. Geological Society of America, Abstracts Programs, 20, p. 60.

OSBERG, P.H. 1978. Synthesis of the geology of the northeast Appalachians, USA. IGCP Project 27, U.S.A., Contribution No. 1, Caledonian - Appalachian Orogen of the North Atlantic Region. Geological Survey of Canada, Paper 78-13, pp. 137147.

OSBERG, P.H. 1980. Stratigraphic and Structural relations in the turbidite sequence of south-central Maine. In A guidebook to the geology of northeastern Maine and Neighboring New Brunswick. Edited by D.C. Roy and R.S. Naylor. New England Intercollegiate Geological Conference, 72nd Annual Meeting, pp. 278-289.

OSBERG, P.H., Hussey, A.M., \& BooNe, G.M. 1985. Bedrock geologic map of Maine. Geological Survey of Maine, Augusta, Maine.

PEARCE, J.A. 1983. The role of sub-continental lithosphere in magma genesis at destructive plate margins. In Continental basalts and mantle xenoliths. Edited by C.J. Hawkesworth and M.J. Norry Nantwich, Shiva, pp. 230-249.

PITCHER, W.S. 1985. A multiple and composite batholith. In Magmatism at a Plate Edge. Edited by W.S. Pitcher, M.P. Atherton, E.J. Cobbing and R.D. Beckinsdale. Blackie and Son, pp. 93-101.

RANKIN, D.W. 1994. Continental margin of the eastern United States: Past and present. In Phanerozoic Evolution of North American Continent-Ocean Transitions. Edited by R.C. Speed. Geological Society of America DNAG Continent-Ocean Volume, pp. 129218.

RAST, N., \& SKEhan, J.W. 1993. Mid-Paleozoic orogenesis in the North Atlantic. In The Acadian orogeny. Edited by D.C. Roy and J.W. Shehan. Geological Society of American, Special Paper 275, pp. 1-25.

Robinson, P., TUCKER, D.R., BRADley, D., BERry, H.N., OSBERG, P.H. 1998. Paleozoic orogens in New England, USA. GFF, 20, 119-148.

RoBINSON, R.G. 1981. Bedrock geology of the Nashua River area, Massachusetts-New Hampshire - Open File Report. United States Geological Survey, $187 \mathrm{p}$.
RoY, D.C., \& MENCHER, E. 1976. Ordovician and Silurian stratigraphy of northeastern Aroostook County, Maine. In Contributions to the Stratigraphy of New England. Edited by L.R. Page. Geological Society of America, Memoir 148, pp. 2552.

SHEARER, C.K., \& ROBINSON, P. 1988. Petrogenesis of metaluminous and peraluminous tonalites within the Merrimack synclinorium: Hardwick Tonalite, central Massachusetts. American Journal of Science, 288-A, pp. 148-195.

SUN, S.-S., AND MCDONOUGH, W.F. 1989. Chemical and isotopic systematics of oceanic basalts: Implications for mantle composition and processes. In Magmatism in the Ocean Basins. Edited by A.D. Saunders and M.J. Norry. Geological Society of London, Special Publication 42, pp. 313-345.

SUNDEEN, D.A. 1971. The bedrock geology of the Haverhill 15, quadrangle, New Hampshire. New Hampshire Department of Resources and Economic Development, Bulletin 5, 119 pp.

TAtsumi, Y., \& Eggins, S. 1995. Subduction Zone Magmatism. Blackwell Science, Inc., 211 p.

Thompson, J.A., Peterson, V.L., Berry, H.N., \& Barreiro, B. 1992. Recent studies in the Acadian metamorphic high, southcentral Massachusetts. In Guidebook for field trips in the Connecticut Valley region of Massachusetts and adjacent states. Edited by P. Robinson and J.B. Brady. Department of Geology and Geography, University of Massachusetts, 66, Vol. 1, pp. 229-255.

TUCKER, R.D., \& RoBInson, P. 1995. U-Pb Age of the Hardwick pluton and pre "dome stage" pegmatite, Quabbin reservoir, and their bearing on the "Acadian" orogeny in central Massachusetts. Geological Society of America, Abstracts with Programs, 27, pp 223-224.

WELLS, P.R.A. 1978. Pyroxene thermometry in simple and complex systems. Contributions to Mineralogy and Petrology, 62, pp. 129-139.

WEST, D.P.JR. 1999. Timing of displacements along the Norumbega fault system, south-central and south-coastal Maine. In Norumbega Fault System of the Northern Appalachians. Edited by A. Ludman and D.P. West Jr. Geological Society of America, Special Paper 331, pp. 167-178.

West, D.P., JR., Lux, D.R., \& HuSSEY, A.M., II 1993. Contrasting thermal histories across the Flying Point Fault, southwestern Maine; evidence for Mesozoic displacement. Geological Society of America Bulletin 105, pp. 1478-1490.

White, A.J.R., WIlliams, I.S., \& Chappell, B.W. 1977. Ultrametamorphism and granitoid genesis. Tectonophysics, 43, pp. 7-22.

Williams, H., \& HATChER, R.D., JR. 1983. Appalachian suspect terranes. In Contributions to the Tectonics and Geophysics of Mountain Chains. Edited by R.D. Hatcher, H. Williams and I. Zietz Jr. Geological Society of America, Memoir, 158, pp. 3353.

WINTSCH, R.P., \& SUTTER, J.F. 1986. A tectonic model for the late Paleozoic of southeastern New England. J. Geology, 94, 459472.

WINTSCH, R.P., SUTTER, J.F., KUNK, M.J., ALEINIKOFF, J.N., \& DORAIS, M.J. 1992. Contrasting P-T-t paths: Thermochronologic evidence for a late Paleozoic assembly of the Avalon composite terrane in the New England Appalachians. Tectonics, 11, pp. 672-689.

WintSCH, R.P., SutTer, J.F., KUNK, M.J., AleinikofF, J.N., \& BOYD, J.L. 1993. Alleghenian assembly of Proterozoic and Paleozoic lithotectonic terranes in south central New England: New constraints from geochronology and petrology. In Field Trip Guidebook for the Northeastern United States: 1993 Boston GSA. Edited by J.T. Cheney, J.T., and Hepburn. Department of Geology and Geography, University of Massachusetts, Amherst, MA. Contribution No. 67, pp. H1-H30. 
WOOD, B.J., \& BANNO, S. 1973. Garnet-orthopyroxene and orthopyroxene-clinopyroxene relationships in simple and complex systems. Contributions to Mineralogy and Petrology, 42, pp. $109-124$.

WoOD, D.A., JoRon, J.L., \& TREulL, M. 1979. A re-appraisal of the use of trace elements to classify and discriminate between magma series erupted in different tectonic settings. Earth and Planetary Science Letters, 45, pp. 326-336.

Wyborn, D., TURner, B.S., \& CHAPPELl, B.W. 1987. The Boggy Plain supersuite: A distinctive belt of I-type igneous rocks of potential economic significance in the Lachlan Fold Belt. Australian Journal of Earth Sciences, 34, pp. 21-43.

ZARTMAN, R.E. 1988. Three Decades of geochronological studies in the New England Appalachians. Geological Society of America Bulletin, 100, pp. 1168-1180.
ZARTMAN, R.E., AND NAYLOR, R.S. 1984. Structural implications of some radiometric ages of igneous rocks in southeastern New England. Geological Society of America Bulletin, 95, pp. 522539.

ZEN, E-AN, 1983. Exotic terranes in the New England Appalachians Limits, candidates and ages: A speculative essay. In Contributions to the Tectonics and Geophysics of Mountain Chains. Edited by R.D. Hatcher Jr., H. Williams and I. Zeitz. Geological Society of America, Memoir 158, pp. 55-81.

Zen, E-an, Goldsmith, R., Ratcliff, N.M., Robinson, P., \& STANLEY, R.S. 1983. Bedrock geologic map of Massachusetts, United States Geological Survey, Scale 1:250,000.

Editorial responsibility: Sandra M. Barr 